This is the peer reviewed version of the following article: [Yao, L.; Rahmanudin, A.; Jeanbourquin, X. A.; Yu, X.; Johnson, M.; Guijarro, N.; Sekar, A.; Sivula, K. Catalyst-Free, Fast, and Tunable Synthesis for Robust Covalent Polymer Network Semiconducting Thin Films. Advanced Functional Materials 2018, 28 (17), 1706303] which has been published in final form at [ http://doi.org/10.1002/adfm.201706303 ]. This article may be used for noncommercial purposes in accordance with Wiley Terms and Conditions for Self-Archiving.

\title{
Catalyst-free, Fast and Tunable Synthesis for Robust Covalent Polymer Network Semiconducting Thin Films
}

Liang Yao, Aiman Rahmanudin, Xavier A. Jeanbourquin, Xiaoyun Yu, Melissa Johnson, Néstor Guijarro, Arvindh Sekar, and Kevin Sivula*

Dr. L. Yao, A. Rahmanudin, X. A. Jeanbourquin, Dr. X. Yu, Dr. M. Johnson, Dr. N. Guijarro, A. Sekar, Prof. K. Sivula

Laboratory for Molecular Engineering of Optoelectronic Nanomaterials

École Polytechnique Fédérale de Lausanne (EPFL)

Station 6, 1015 Lausanne, Switzerland

E-mail: kevin.sivula@epfl.ch

Keywords: covalent polymer networks $\bullet$ organic semiconductor films $\bullet$ organic solar cells $\bullet$ thermal alkyne-azide cycloaddition $\bullet$ self-assembly

ABSTRACT: Covalent polymer networks (CPNs) are of great technological interest due to their robustness and tunability, however they are rarely applied as semiconductors in optoelectronic devices due to poor material processibility. Herein, we report a simple, rapid, and powerful approach to prepare CPN thin-films based on an in-situ thermal azide-alkyne cycloaddition (TAAC) in the absence of catalyst or solvent. Our method is demonstrated with perylenediimide and triazine-based monomers and affords smooth and homogenous CPN films through solution processing and heat-treatment (10 min). Moreover, the site-specific TAAC realizes semiconducting CPNs without undesired impurities or byproducts, and tunable optoelectronic properties are achieved by varying the reaction temperature, which affects the intermolecular self-assembly. The obtained CPN films exhibit exceptional solvent resistance, and good n-type semiconducting behavior, which together afford application in a series of multilayer solution-processed organic photovoltaics where the presence of CPN films significantly improves the solar energy conversion efficiency to over $8 \%$ (7\% in control devices) when the CPN is used in a planar-mixed heterojunction device architecture. 


\section{Introduction}

Solution-processable semiconducting organic polymers have revolutionized the field of organic electronics by enabling the scalable roll-to-roll fabrication of solar cells, light emitting diodes, and transistors. ${ }^{[1-5]}$ However, improving the robustness of these materials is required for viable commercial application. A relatively new class of materials, organic covalent polymer networks (CPNs), possess attractive advantages over traditional linear polymers such as superior chemical stability, solvent resistance, and mechanical robustness due to their interconnected molecular structure. ${ }^{[6-7]}$ While a wide variety of CPNs have been demonstrated as promising materials for gas separation, storage, and other fields, ${ }^{[8-10]}$ employing CPNs in organic electronic devices is still relatively unexplored. Although the excellent robustness of CPNs is potentially attractive for enhancing the stability of organic semiconductor devices, and their solvent resistance could also facilitate the fabrication of solution-processable multilayer devices, the poor processibility of CPNs has severely limited their application. Indeed, typical CPN preparation routes lead to insoluble and intractable powders. While spin-coating powder dispersions ${ }^{[11]}$ has been described, such an approach does not offer high quality, continuous large-area thin films. Chemical bath deposition ${ }^{[12-13]}$ and (gas/liquid) interfacial film growth ${ }^{[14]}$ have also been recently reported, leading to initial device demonstrations with CPNs. However, these synthesis routes are slow-on the order of tens of hours-which seriously diminishes the potential for scalability. While electro-polymerization has also been considered as an alternative method for CPN thin film fabrication, ${ }^{[15-19]}$ this method is limited to a small subset of monomers (containing carbazole, thiophene, or triphenylamine groups with sufficient electron-donating character). In addition, a non-negligible amount of electrolyte remains in the film, which can be detrimental to optoelectronic performance. ${ }^{[20-21]}$ Therefore, in order to advance the application of $\mathrm{CPNs}$ in solution-processed organic 
electronic devices, a rapid and direct film fabrication approach that combines simplicity with high quality film formation and tunable optoelectronic performance is urgently needed.

In this context, we report herein a novel fabrication method to overcome the challenge of CPN film fabrication, which is realized by the use of a catalyst-free thermal alkyne-azide cycloaddition (TAAC) ${ }^{[6,22-24]}$ reaction. The CPN thin films are rapidly obtained through the in-situ heat treatment of a blend film containing alkyne- and azide-based monomers, and since the TAAC reaction affords site-specific bond-formation in the absence of catalyst or additional solvent, our method enables a "pure" and well-defined CPN thin film. Compared to the known strategy of cross-linking linear polymers ${ }^{[25-29]}$, the approach demonstrated herein offers the advantages of synthetic simplicity and less batch-to-batch variation as only smallmolecule precursors are used. In addition, the polymer cross-linking approach frequently requires the addition of initiator and exhibits a non-specific reaction mechanism, which has a negative impact on the optoelectronic performance. ${ }^{[30-32]}$ Our results indicate that the TAAC reaction described herein possess a high specificity, which clearly provides a major advantage. Our method enables the fabrication of smooth and homogeneous CPN films with thermally stable homogenous morphology, favorable solvent resistance, and tunable optoelectronic properties directly on a wide variety of substrates. We further demonstrate the application of these robust CPN films in solution-processed multilayer organic solar cells where introducing CPN films is shown to be a versatile method to improve the solar energy conversion efficiency. 


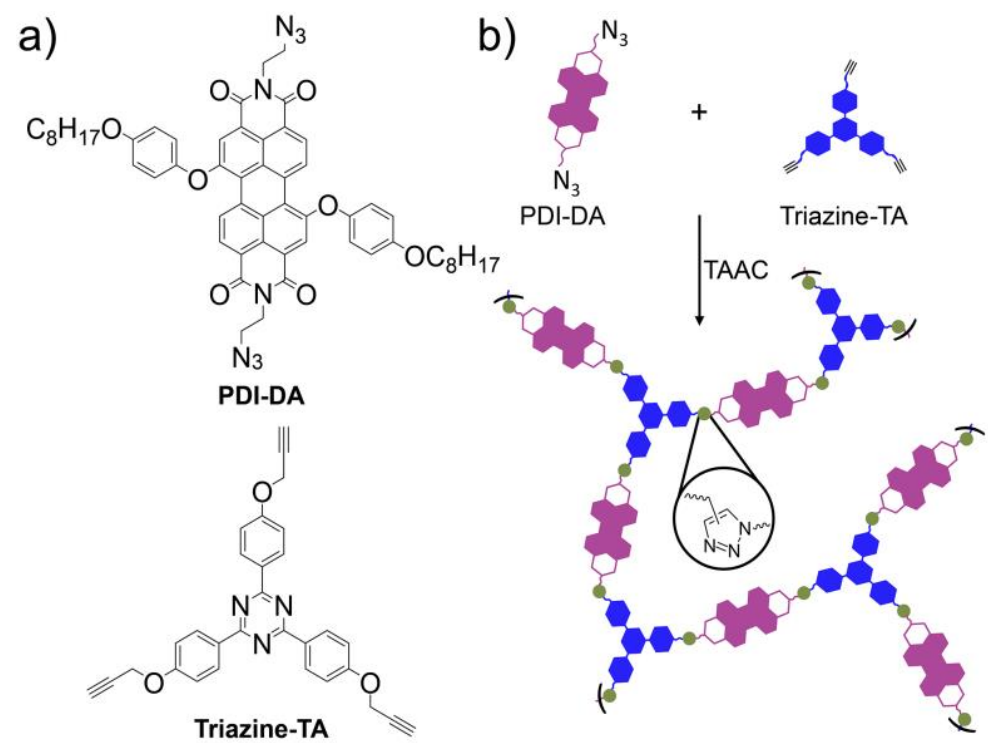

Figure 1. a) Molecular structure of the PDI-DA and Triazine-TA monomers and b) a schematic representation of the CPN synthesis.

\section{Results and Discussion}

\subsection{Catalyst- and Solvent- free synthesis of CPNs}

To demonstrate the TAAC-based CPN formation, two monomers, PDI-DA and Triazine-TA (Figure 1a), were rationally designed and prepared. Perylenediimide (PDI) was chosen as it is an extensively investigated building block for organic n-type materials. ${ }^{[33]} \mathrm{We}$ included azidoethyl groups at the imide position of PDI for the TAAC reaction and 4(octyloxy)phenoxy groups at the bay positions to increase solubility. For Triazine-TA, electron-withdrawing alkynes were selected to accelerate the TAAC reaction rate. ${ }^{[6,23,34-35]}$ Full synthetic procedures of PDI-DA and Triazine-TA are described in supporting information (Scheme S1). Before running the TAAC reaction (shown schematically in Figure 1b), the thermal stability of the two monomers was evaluated using thermogravimetric analysis (Figure S1), and ${ }^{1} \mathrm{H}$ NMR (Figure S2), which indicated monomer stability to $200{ }^{\circ} \mathrm{C}$. To test the TAAC solid state reaction, we prepared a solid-state mixture of PDI-DA and Triazine-TA. The two monomers were first dissolved in chloroform at a 1:1 molar ratio of azide to alkyne, and a solid-state mixture was prepared by evaporating the chloroform. The mixture was heated at a reaction temperature, $\mathrm{T}_{\mathrm{rxn}}$, of $180{ }^{\circ} \mathrm{C}$ for 1 hour under argon and 
insoluble CPN powder was formed implying the TAAC reaction occurs at temperatures below decomposition. The reaction yield was estimated from the mass of resulitng insoluble powder compared to the mass of the monomers before the TAAC reaction. A low mass yield (47\%) found under these conditions is attributed to a $\mu \mathrm{m}$-scale phase segregation between monomers in the evaporated mixture as shown by optical microscopy (Figure S3). For the insoluble CPN powder, the intensity of the PDI-DA azide group IR stretch at $2103 \mathrm{~cm}^{-1}$ and the triple bond stretch at $2119 \mathrm{~cm}^{-1}$ of Triazine-TA are significantly suppressed (Figure 2a). In the solid-state MAS ${ }^{13} \mathrm{C}$ NMR spectra (Figure 2b, see reference in Figure S4), the alkynyl carbon signals (marked b, c) of Triazine-TA (at 80.2 and $77.4 \mathrm{ppm}$ ) are diminished in the CPN powder. Notably, the Triazine-TA methylene signal (marked a) shifts from $55.4 \mathrm{ppm}$ to $61.1 \mathrm{ppm}$ in the CPN powder, ascribed to the formation of triazole (in good agreement with a previous report $\left.{ }^{[23]}\right)$. In addition, the formed triazole also induces the ${ }^{13} \mathrm{C}$ signal shift of methylene in PDI-DA (marked d). The mass spectra of the soluble products (Figure S5) indicates a mixture of oligomers with observed molecular weights matching well with predicted values, suggesting no unknown side reactions occur. Overall these characterization results confirm the success and specificity of the solid-state TAAC reaction between PDI-DA and TriazineTA.
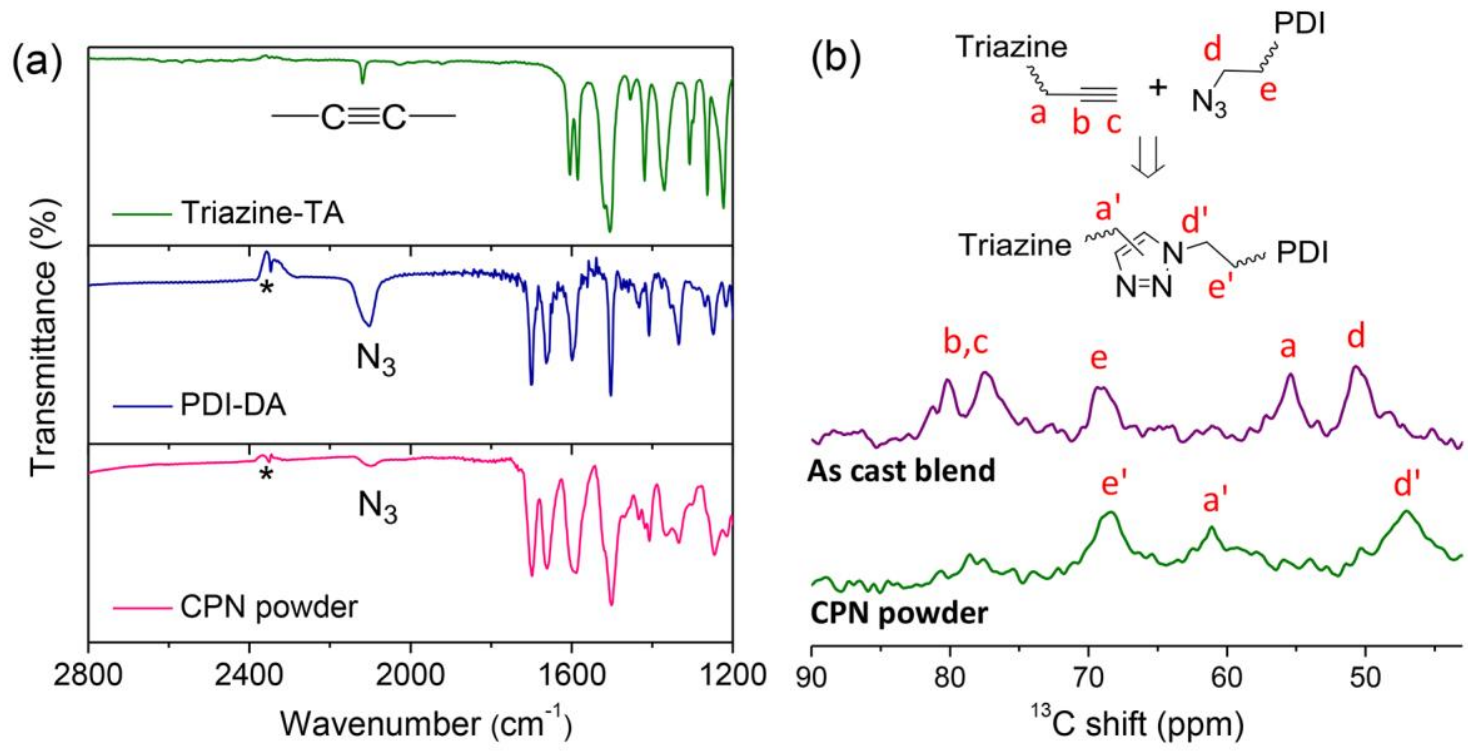
Figure 2. (a) FT-IR spectra of Trianzine-TA, PDI-DA and insoluble CPN powder (with asterisk indicating $\mathrm{CO}_{2}$ stretch). (b) ${ }^{13} \mathrm{C}$ solid-state MAS-NMR of the as-cast blend and insoluble $\mathrm{CPN}$ powder and a schematic of the assigned peaks.

\subsection{Morphology of the CPN thin films}

To afford CPN thin films, blend solutions of PDI-DA and Triazine-TA were spin-coated onto glass or ITO substrates. We found the solvent to be critical for film formation. While processing from chlorobenzene (CB) led to $\mu \mathrm{m}$-scale phase segregation (Figure S6), chloroform (CF) gave smooth and homogeneous films with no detectable phase separation, even after treating at $\mathrm{T}_{\mathrm{rxn}}=180{ }^{\circ} \mathrm{C}$ (Figure S7). Varying the concentration of the $\mathrm{CF}$ solution afforded a tunable film thickness between 10-100 nm without changing the film homogeneity. UV-vis spectra of thin-films after heating for different times (Figure 3a) give insight into the progress of the CPN film formation. The as-cast blend film displays a broad absorption with peaks at $670 \mathrm{~nm}$ and $494 \mathrm{~nm}$ attributed to $\pi-\pi$ stacking of PDI-DA (the peak at $305 \mathrm{~nm}$ is due to Triazine-TA, see Figure S8). Heating at $180{ }^{\circ} \mathrm{C}$ causes the peak at $670 \mathrm{~nm}$ to decrease while a new absorption band appears at $570 \mathrm{~nm}$. This new band has nearly the same position as PDI-DA in dilute solution (Figure 3 a bottom), thus we assign it to non- $\pi$ - $\pi$-stacked PDI in the solid state films. The growth of the $570 \mathrm{~nm}$ band with heat treatment suggests that the $\pi-\pi$ stacking is progressively disrupted as the TAAC reaction occurs, as expected from the covalent bonding between PDI and triazine. It is worth noting that the formation of CPN films is very fast: an obvious change of absorption is observed after heating for only $10 \mathrm{~s}$, and no change is seen after $10 \mathrm{~min}$. 

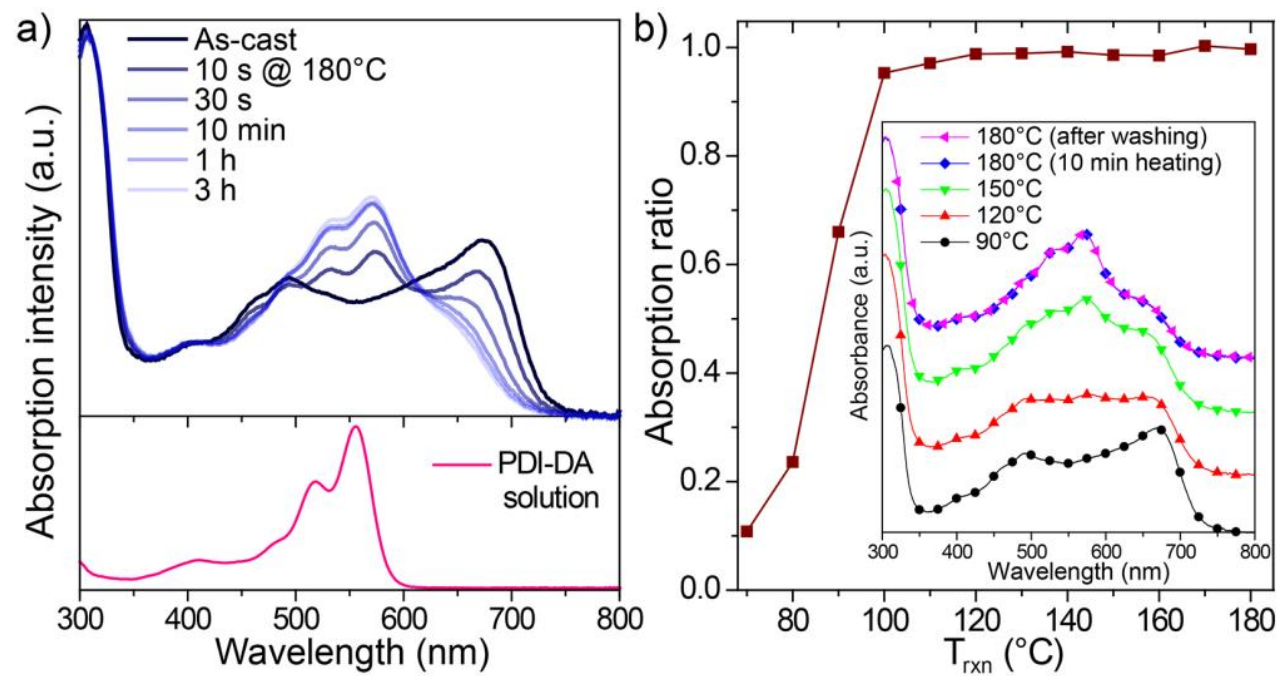

Figure 3. (a) UV-vis spectra of (top) the blend thin film heated at $180{ }^{\circ} \mathrm{C}$ for different times and (bottom) the PDI-DA solution $\left(10^{-5} \mathrm{~mol} \mathrm{~L}^{-1}\right.$ in THF). (b) The absorption ratio (i.e. the ratio of UV-vis absorption at $570 \mathrm{~nm}$ after washing the film with $\mathrm{CB}$ to before washing) as a function of thermal treatment $\left(\mathrm{T}_{\mathrm{r} \times n}\right.$ for $\left.10 \mathrm{~min}\right)$. The inset figure shows the UV-vis spectra of the blend film treated at various $\mathrm{T}_{\mathrm{rxn}}$ for $10 \mathrm{~min}$ and after washing in $\mathrm{CB}$ for the $180{ }^{\circ} \mathrm{C}$ film.

Varying the reaction temperature, $\mathrm{T}_{\mathrm{rxn}}$, from $90-180{ }^{\circ} \mathrm{C}$ (10 min heating, Figure $3 \mathrm{~b}$ inset) showed a similar effect on the UV-vis spectra compared to varying heating time at $180{ }^{\circ} \mathrm{C}$ and the extent of the TAAC reaction could be further probed by assessing the solvent resistance of the resulting CPN film (by washing with CB). For films treated at $180^{\circ}$ for 10 min there was no change in the UV-vis spectra after washing (Figure $3 b$ inset). The ratio of the UV-vis absorption after/before $\mathrm{CB}$ washing as a function of $\mathrm{T}_{\mathrm{rxn}}$ is shown in Figure $3 \mathrm{~b}$ (see also Figure S9) and suggests that 10 min heating at $120{ }^{\circ} \mathrm{C}$ is sufficient to prepare a robust insoluble CPN film. Notably, the TAAC reaction between PDI-DA and Triazine-TA is much faster than that of polystyrene functionalized with azide and alkyne ${ }^{[23]}$, where insoluble products only obtained after more than $30 \mathrm{~min}$ heating at $120{ }^{\circ} \mathrm{C}$. The faster reaction is probably due to the better mobility and vibration of reactive groups in small molecule monomers. For $\mathrm{T}_{\mathrm{rxn}}<100{ }^{\circ} \mathrm{C}$ the absorption ratio decreased due to the removal of soluble oligomers and unreacted monomer. Interestingly, we note that while films treated at $\mathrm{T}_{\mathrm{rxn}}$ of 120-180 ${ }^{\circ} \mathrm{C}$ all exhibit robust insoluble CPN film formation, their significantly different UV- 
vis spectra imply a tunable $\pi-\pi$ stacking and self-assembly that reasonably should influence the charge carrier transport in the CPN film (vide infra). In addition to solvent resistance in $\mathrm{CB}$, we note that the $\mathrm{CPN}$ films possess solvent resistance for many other common organic solvents (Figure S10).

Morphological characterization of the thin films prepared by spin-coating from $\mathrm{CF}$ solutions showed homogeneity from the $\mathrm{nm}$ to $\mathrm{mm}$ length scales. Atomic force microscopy (AFM, Figure 4a) shows that an as-cast blend film is smooth (RMS roughness of $4.2 \mathrm{~nm}$ ) with granular domains less than $100 \mathrm{~nm}$ in lateral dimension. After heating for $10 \mathrm{~min}$, the domain boundaries are softened, and the RMS roughness decreases to $3.6 \mathrm{~nm}\left(120{ }^{\circ} \mathrm{C}\right), 3.3$ $\mathrm{nm}\left(150{ }^{\circ} \mathrm{C}\right)$ and $2.7 \mathrm{~nm}\left(180{ }^{\circ} \mathrm{C}\right)$ (see Figure S11). This smoothing of the topography is consistent with the formation of fewer PDI aggregates as suggested by the UV-vis data. A decrease in crystallinity as a result of the CPN formation is further supported by grazing incident wide angle X-ray scattering (GIWAXS). Out-of-plane scans (Figure S12), show that the scattering peaks of the as-cast film become less pronounced after heating, in good agreement with the UV-vis spectra and AFM data. Notably, the film morphology remains unchanged after heating for 2 hours at $\mathrm{T}_{\mathrm{rxn}}=120^{\circ} \mathrm{C}$ or $180{ }^{\circ} \mathrm{C}$ (Figure S13) indicating excellent thermal stability of the CPN films. 


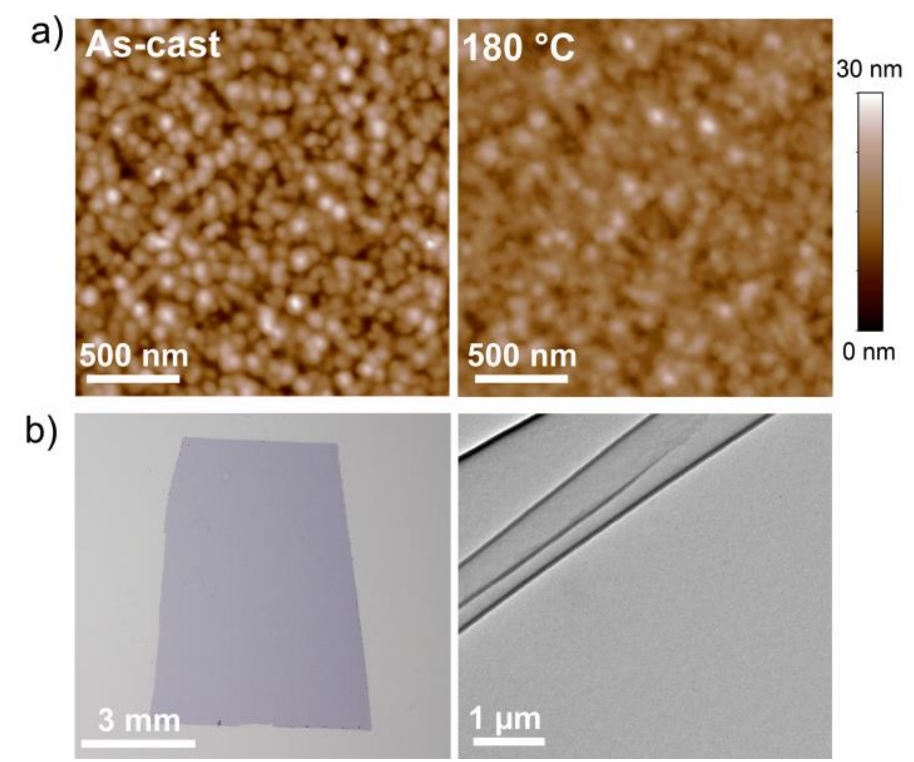

Figure 4. (a) AFM images of the as-cast film and the CPN film obtained after $10 \mathrm{~min}$ annealing at $180{ }^{\circ} \mathrm{C}$. (b) Image of the CPN free-standing film (left) with the thickness of 35 $\mathrm{nm}$ delaminated from an ITO substrate. A TEM image (right) of the folded edge of the freestanding film is also shown.

The robustness of the CPN films are further demonstrated by delaminating a $35 \mathrm{~nm}$ thick CPN film from an ITO substrate (via dilute $\mathrm{HCl}$ etching). The resulting free-standing film (ca. $0.4 \mathrm{~cm}^{2}$ see Figure $4 \mathrm{~b}$ ) retains mechanical integrity and can be easily transferred to any substrate. Transmission electron microscopy (Figure 4b) and optical microscopy (Figure S14) further demonstrate that the free-standing CPN film is homogeneous over $\mu \mathrm{m}$ to $\mathrm{mm}$ length scales.

\subsection{Electron mobility of the CPN films}

As the optoelectronic performance of the CPN is of particular interest, thin films were next investigated as active layers in organic field effect transistors (OFETs). Bottom-gate bottomcontact devices were fabricated as described in the experimental section and the extracted saturation-regime electron mobility, $\mu_{\text {sat }}$, as a function of $T_{r x n}$ and heating time is shown in Figure 5a (for transfer curves see Figure S15). The as-cast film exhibited $\mu_{\text {sat }}=1.1 \times 10^{-5} \mathrm{~cm}^{2}$ $\mathrm{V}^{-1} \mathrm{~s}^{-1}$. This relatively low electron mobility is likely due to the bulky substituents on the PDI bay-region, which affect the planarity of $\mathrm{PDI}^{[36]}$ and negatively impact the intermolecular charge transport. This issue could be resolved by further optimization of molecular 
structure ${ }^{[33]}$ After heating the blend film for $10 \mathrm{~min}, \mu_{\mathrm{sat}}$ slightly increased when $\mathrm{T}_{\mathrm{rxn}}=90{ }^{\circ} \mathrm{C}$, and decreased for films treated at higher $\mathrm{T}_{\mathrm{rxn}}$ (when CPN formation occurs) consistent with the decrease in film crystallinity and loss of aggregation observed in the UV-vis results. This observation further validates the ability to tune the optoelectronic performance of the CPN film. Importantly, heating at $120{ }^{\circ} \mathrm{C}$ or $150{ }^{\circ} \mathrm{C}$ reduced $\mu_{\text {sat }}$ by less than factor of 10 while still forming a robust CPN. In fact, $\mu_{\text {sat }}$ remained essentially constant over a 2-hour heating period (Figure 5a) indicating thermal stability, and solvent resistance (tested by soaking CPN transistors prepared at $150{ }^{\circ} \mathrm{C}$ in $\mathrm{CB}$ and retesting repeatedly over 2 hours) was further verified by exhibiting an insignificant effect on $\mu_{\text {sat }}$ after a small initial decrease (Figure $5 b$ ). In contrast, the as-cast blend film of PDI-DA and Triazine-TA completely loses electrical signal after 5 min soaking in CB (Figure S16) due to the dissolution of the film in the CB (see photograph of soaking solution Figure $5 b$ inset).
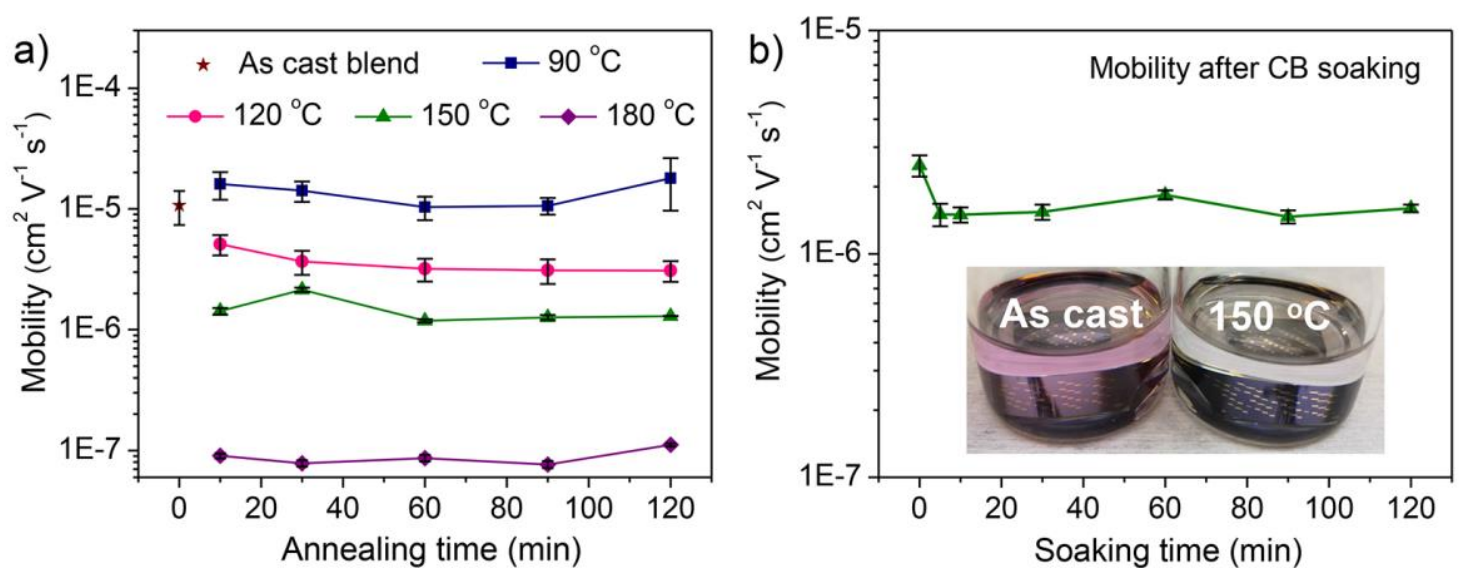

Figure 5. (a) The average $\mu_{\text {sat }}$ of CPN films as a function of $T_{\mathrm{rxn}}$ and time. (b) The average $\mu_{\text {sat }}$ of a CPN film $\left(\mathrm{T}_{\mathrm{rxn}}=150{ }^{\circ} \mathrm{C}\right)$ as a function of $\mathrm{CB}$ soaking time. The inset image displays the transistors based on as-cast blend and CPN films in CB after soaking for $2 \mathrm{~h}$.

\subsection{The application of the CPN films in solar cells}

The tunability and robustness of the CPN electronic properties even under solvent soaking suggests their effectiveness in applications that require solvent-tolerance, such as solutionprocessed multilayer device fabrication. To demonstrate this, planar heterojunction (PHJ) organic photovoltaic devices (OPVs) were studied using CPN films as the acceptor layer, and 
common linear polymers P3HT or PTB7 as the donor (See molecular structures Figure 6a). Firstly, we established the HOMO/LUMO levels the CPN film at $-5.9 \mathrm{eV}$ and $-3.7 \mathrm{eV}$, respectively (Figure $S 17 \mathrm{a}$ ), and found these levels to be invariant with $\mathrm{T}_{\mathrm{rxn}}$. Since this energy level alignment is suitable for exciton dissociation at the CPN/PTB7 or CPN/P3HT interface (Figure S17b), we next fabricated inverted PHJ OPVs (active areas of $16 \mathrm{~mm}^{2}$ ) with the configuration of $\mathrm{ITO} / \mathrm{ZnO} / \mathrm{CPN} /(\mathrm{PTB} 7$ or $\mathrm{P} 3 \mathrm{HT}) / \mathrm{MoO}_{3} / \mathrm{Ag}$ (see schematic Figure $6 \mathrm{a}$ ) by directly spin coating PTB7 or P3HT on the formed CPN. Device fabrication conditions were optimized (e.g. CPN film thickness and $\mathrm{T}_{\mathrm{rxn}}$, see Table S2), and the current density-voltage (JV) curves of the optimized devices are shown in Figure 6b. The CPN/PTB7 PHJ device at optimized conditions achieves an average power conversion efficiency (PCE) of $0.53 \%$, an open-circuit voltage $\left(\mathrm{V}_{\mathrm{oc}}\right)$ of $0.73 \mathrm{~V}$, a short circuit current $\left(\mathrm{J}_{\mathrm{sc}}\right)$ of $1.65 \mathrm{~mA} \mathrm{~cm}{ }^{-2}$, and a fill factor (FF) of $45 \%$. The CPN/P3HT PHJ device exhibits a $\mathrm{V}_{\mathrm{oc}}$ of $0.53 \mathrm{~V}$, a $\mathrm{J}_{\mathrm{sc}}$ of $1.73 \mathrm{~mA} \mathrm{~cm}^{-}$ 2, a FF of $0.53 \%$ and an average PCE of $0.52 \%$. The external quantum efficiency (EQE) spectra of the optimized PHJ devices are displayed in Figure S18 and photons absorbed by the CPN layer actively contribute to photocurrent for both CPN/PTB7 and CPN/P3HT devices. Notably, the CPN/P3HT PHJ device achieved a comparable performance with reported bulk heterojunction (BHJ) devices based on mono PDI acceptors and P3HT (See Table S3) although it is well known that the performance of PHJs are inferior to that BHJs due to a limited donor-acceptor interfacial area. ${ }^{[37-38]}$ Nevertheless the PHJ device results confirm the promising potential of CPN films in the construction of solution-processed multi-layer optoelectronic devices. 

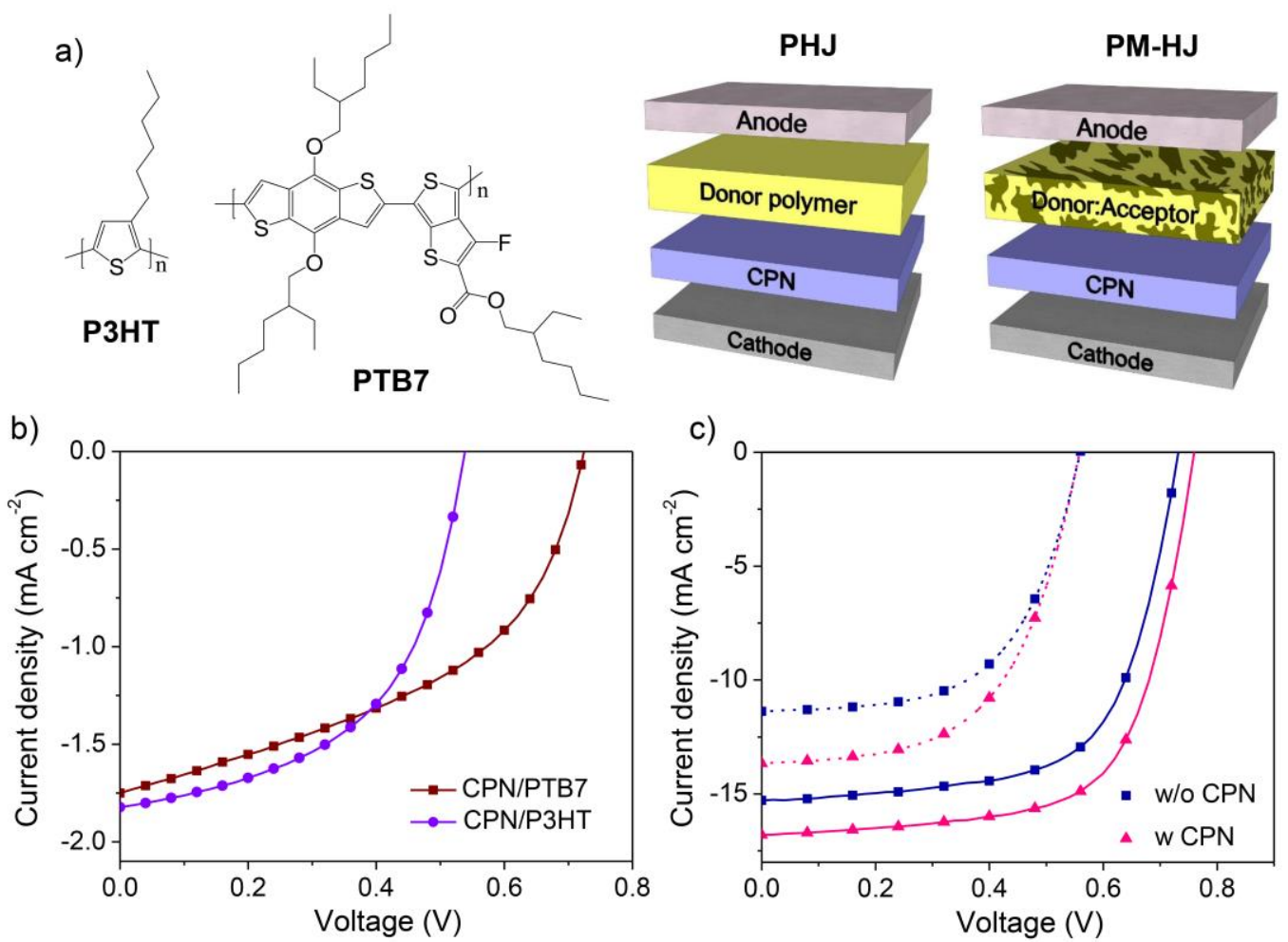

Figure 6. (a) Molecular structure of polymer donor and planar heterojunction (PHJ) and planar-mixed heterojunction (PM-HJ) device configurations. (b) $\mathrm{J}-\mathrm{V}$ characteristics of the optimized CPN/PTB7 and CPN/P3HT PHJ devices. (c) J-V characteristics of the hybrid planar-mixed heterojunction $(\mathrm{PM}-\mathrm{HJ})$ devices with or without $\mathrm{CPN}$ processed at $\mathrm{T}_{\mathrm{rxn}}=$ $120{ }^{\circ} \mathrm{C}$. The dashed curves represent $\mathrm{P} 3 \mathrm{HT}: \mathrm{PC}_{61} \mathrm{BM}$ bulk heterojunction $(\mathrm{BHJ})$ devices, and the solid curves represent PTB7:PC ${ }_{71} \mathrm{BM}$ BHJ devices.

The suitability of our CPN preparation for robust optoelectronic application was further demonstrated by employing films as interfacial layers in $\mathrm{PTB} 7: \mathrm{PC}_{71} \mathrm{BM}$ or $\mathrm{P} 3 \mathrm{HT}: \mathrm{PC}_{61} \mathrm{BM}$ BHJ OPVs by coating the BHJ on top of the CPN film giving a planar-mixed heterojunction $(\mathrm{PM}-\mathrm{HJ}) \mathrm{OPV}^{[39-40]}$ with a final configuration of $\mathrm{ITO} / \mathrm{ZnO} / \mathrm{CPN} /\left(\mathrm{PTB} 7: \mathrm{PC}_{71} \mathrm{BM}\right.$ or P3HT:PC 61 BM)/MoO$/ \mathrm{Ag}$ (See device schematic Figure $6 \mathrm{a}$ ). The J-V curves of optimized devices are shown in Figure 6c, and the device metrics are summarized in Table S4. The control PTB7:PC $\mathrm{P}_{71} \mathrm{BM}$ BHJ device without a CPN layer shows an average PCE of $6.95 \%$ with a $\mathrm{V}_{\mathrm{oc}}$ of $0.73 \mathrm{~V}$, a $\mathrm{J}_{\mathrm{sc}}$ of $14.9 \mathrm{~mA} \mathrm{~cm}^{-2}$, and a $\mathrm{FF}$ of $67 \%$. When adding a CPN layer prepared at $\mathrm{T}_{\mathrm{rxn}}=120{ }^{\circ} \mathrm{C}$ an enhanced $\mathrm{V}_{\mathrm{oc}}$ of $0.75 \mathrm{~V}$ and $\mathrm{J}_{\mathrm{sc}}$ of $16.7 \mathrm{~mA} \mathrm{~cm}{ }^{-2}$ is observed leading to an average PCE of $7.94 \%$ (highest PCE of $8.19 \%$ ). The improvement in both the $\mathrm{V}_{\mathrm{oc}}$ and the $\mathrm{J}_{\mathrm{sc}}$ suggest a reduced recombination at the electron-collecting cathode interface 
due to the presence of the CPN. Similarly, the PCE of P3HT:PC ${ }_{61} \mathrm{BM}$ PM-HJ device is improved from $3.34 \%$ to $4.17 \%$. We note a that the PM-HJ devices with $\mathrm{T}_{\mathrm{rxn}}=150{ }^{\circ} \mathrm{C}$ and $180{ }^{\circ} \mathrm{C}$ show a slightly reduced PCE compared to $\mathrm{T}_{\mathrm{rxn}}=120^{\circ} \mathrm{C}$ (Figure S19), likely due to the lower electron mobility of the CPN film prepared at these condition.

\section{Conclusion}

In summary, we developed for the first time, a simple and rapid solution-processable fabrication approach for tunable CPN semiconductor thin films using an in-situ catalyst-free and solvent-free TAAC reaction. Importantly, our approach enables the rapid formation of CPN films without introducing impurities or side reactions. The CPN films prepared from PDI-DA and Triazine-TA films possess smooth and homogenous morphology with favorable thermal stability, and more importantly, excellent solvent resistance. By varying the temperature and time of the TAAC reaction we demonstrate tunability of the film selfassembly and resulting optoelectronic properties. To verify their effectiveness, our CPN films were employed in multi-solution-processed-layer devices as an acceptor layer in PHJ solar cells and as an interfacial layer in hybrid PM-HJ solar cells. The performance of the optimized CPN/P3HT PHJ devices were comparable to BHJ solar cells based on monomer PDI acceptors and P3HT and employing the CPN layers in PM-HJ devices with PTB7:PC ${ }_{71} \mathrm{BM}$ or $\mathrm{P} 3 \mathrm{HT}: \mathrm{PC}_{61} \mathrm{BM}$ BHJs gave significant improvement of $14 \%$ and $25 \%$ in PCE, respectively. Overall, our work provides a synthetic methodology based on the sitespecific TAAC reacion for robust CPN semiconductor films, which exhibit a promising potential in optoelectronic devices that requires solvent tolerant materials. Given the versatile of our approach, we believe that diverse CPNs films tailored to a variety of applications in organic optoelectronics can be accessed through rational monomer design.

\section{Experimental Section}


General measurement: Liquid NMR experiments were performed on Bruker AVANCEIII400 spectrometer. Tetramethylsilane (TMS) was used as the internal standard. For solid state NMR measurements, the two monomers and their blend were filled in $2.5 \mathrm{~mm} \mathrm{ZrO}_{2}$ rotor, and measured with a standard triple channel $(\mathrm{H}, \mathrm{X}, \mathrm{Y}) 2.5 \mathrm{~mm}$ MAS probe in a $400 \mathrm{MHz}$ Bruker instrument. The method was ${ }^{1} \mathrm{H}-{ }^{13} \mathrm{C}$ CP-MAS and the spinning speed $15 \mathrm{kHz}$. The insoluble CPN powder was filled in a $1.3 \mathrm{~mm} \mathrm{ZrO}_{2}$ rotor and measured with a standard triple channel $\left({ }^{1} \mathrm{H},{ }^{13} \mathrm{C},{ }^{15} \mathrm{~N}\right) 1.3 \mathrm{~mm}$ MAS probe in an $800 \mathrm{MHz}$ Bruker instrument. The method was ${ }^{1} \mathrm{H}_{-}{ }^{13} \mathrm{C}$ CP-MAS and the spinning speed $40 \mathrm{kHz}$. Mass spectra were recorded on AutoFlex speed MALDI-TOF mass spectrometer (Bruker), using $\alpha$-cyano-4-hydroxycinnamic (CHCA) as matrix. TGA curves were performed on TGA 4000 from Perkin Elmer. The TGA measurement was carried out under nitrogen, and the heating rate is $10{ }^{\circ} \mathrm{C} \min ^{-1}$. FT-IR spectra were recorded in transmission mode using Perkin Elmer Frontier FT-IR spectrometer. $\mathrm{KBr}$ pellets contained the samples were performed for the measurement. The absorption spectra of the thin films and solutions were tested by Shimazu UV 3600 spectrometer. The AFM images were recorded on Cypher S AFM from Asylum Research. The polymer network films were spin coated on silica wafer substrates. The spin-coating speed is $1000 \mathrm{rpm} \mathrm{min}^{-1}$. Chloroform was utilized to dissolve PDI-DA and Triazine-TA with the concentration of $3 \mathrm{mg}$ $\mathrm{mL}^{-1}$ and $0.97 \mathrm{mg} \mathrm{L}^{-1}$ (the molar ratio between azide and alkyne is $1: 1$ ), respectively.

Transistor device and characterization: Bottom gate bottom contact transistor substrates were purchased from Fraunhofer Institute for Photonic Microsystems. The n-doped silicon wafer is used as bottom gate electrode, and a $230 \mathrm{~nm} \mathrm{SiO}_{2}$ is applied for dielectric layer. Au is used for source and drain electrodes, which is the most commonly used metal for source and drain electrodes in n-type OFETs because of its environmental stability, although its high work function may lead to a decrease of measured electron mobility. The thickness of $\mathrm{Au}$ is $30 \mathrm{~nm}$, and $10 \mathrm{~nm}$ high work function ITO is used as the adhesion layer. The channel length (L) and width (W) are $2.5 \mu \mathrm{m}$ and $10 \mathrm{~mm}$, respectively. The substrates were successively cleaned by 
water, isopropanol, and acetone. After dried by argon, a $35 \mathrm{~nm}$ organic layer was spin coated on the substrates at $1000 \mathrm{rpm}$. The blend of PDI-DA and Triazine-TA were dissolved in chloroform with the concentration of $3 \mathrm{mg} \mathrm{mL}^{-1}$ and $0.97 \mathrm{mg} \mathrm{mL}^{-1}$, respectively. The transistors were annealed in argon glovebox at specified temperature and time. For the chlorobenzene soaking measurement, the transistor was immersed in clean chlorobenzene for specified time. After the transistor was taken out from the chlorobenzene solution, it was dried by argon gun and then subjected to a thermal annealing at $80{ }^{\circ} \mathrm{C}$ for $10 \mathrm{~min}$ in order to remove the remaining chlorobenzene in the film. The current-voltage (I-V) characteristics of the transistors were measured in nitrogen glovebox using a custom-built probe station and a Keithley 2612A dual-channel source measure unit. The electron mobility of the transistors was extracted from saturation regime according to the equation:

$$
\mu=2\left(\frac{\partial \sqrt{I_{D}}}{\partial V_{G S}}\right)^{2} \frac{L}{W C_{i}}
$$

Where L and $\mathrm{W}$ are the channel length and width, respectively. ID is the current between source and drain electrode, and $\mathrm{V}_{\mathrm{GS}}$ is the gate voltage. $\mathrm{C}_{\mathrm{i}}\left(1.4 \times 10^{-8} \mathrm{~F} \mathrm{~cm}^{-2}\right)$ is the capacity of the dielectric layer.

Solar cell fabrication and characterization: $\mathrm{P} 3 \mathrm{HT}$ was purchased from Aldrich, and $\mathrm{PC}_{61} \mathrm{BM}$ and $\mathrm{PC}_{71} \mathrm{BM}$ from Ossila. PTB7 was synthesized according to the literature. ${ }^{[41]}$ Pre-patterned ITO was cleaned by sequential sonication in water, isopropanol and acetone for $30 \mathrm{~min}$ each, and dried by argon. $\mathrm{ZnO}(20 \mathrm{~nm})$ was utilized for the electron transport layer in the inverted solar cells. The $\mathrm{ZnO}$ precursor solution, which contains $0.5 \mathrm{M}$ zinc acetate dehydrate and 0.5 $\mathrm{M}$ monoethanolamine in 2-methoxyethanol, was stirred under $60{ }^{\circ} \mathrm{C}$ for overnight. The $\mathrm{ZnO}$ electron transport layer was deposited on the clean ITO substrates by spin-coating the precursor solution with the spin rate of $5000 \mathrm{rpm}$. After cleaning the electrical contacts, the substrates were annealed at $200{ }^{\circ} \mathrm{C}$ in air for $30 \mathrm{~min}$. The blend solution of PDI-DA and Triazine-TA was prepared in chloroform with the 1:1 molar ratio of azide and alkyne. The 
thickness of the CPN films was optimized by changing the concentration of the blend solution and spin rate. Basically, a $20 \mathrm{~nm}$ film can be obtained from spin-coating the solution contained $3 \mathrm{mg} \mathrm{mL}^{-1}$ PDI-DA and $0.97 \mathrm{mg} \mathrm{mL}^{-1}$ Triazine-TA at $2000 \mathrm{rpm}$. The CPN films were obtained by heating the substrates for $10 \mathrm{~min}$ at different temperatures, and the heating process was carried out in argon glovebox. For planar heterojunction, P3HT was dissolved in chlorobenzene at the concentration of $7 \mathrm{mg} \mathrm{mL}^{-1}, 10 \mathrm{mg} \mathrm{mL}^{-1}$ and $15 \mathrm{mg} \mathrm{mL}^{-1}$. The P3HT solution was spin coated on CPN at $1000 \mathrm{rpm}$, which produced the P3HT layer with the thickness of $40 \mathrm{~nm}, 60 \mathrm{~nm}$ and $90 \mathrm{~nm}$, respectively. PTB7 was dissolved in chlorobenzene at the concentration of $10 \mathrm{mg} \mathrm{mL}^{-1}, 13 \mathrm{mg} \mathrm{mL}^{-1}$ and $18 \mathrm{mg} \mathrm{mL}^{-1}$. The PTB7 layer with the thickness of $45 \mathrm{~nm}, 60 \mathrm{~nm}$ and $85 \mathrm{~nm}$ was deposited on CPN films by spin coating PTB7 solution at $1000 \mathrm{rpm} \mathrm{min}{ }^{-1}$. For hybrid planar mixed heterojunction (PM-HJ), P3HT and $\mathrm{PC}_{61} \mathrm{BM}$ with the mass ratio of 1:0.7 were dissolved in dichlorobenzene contained $1 \%$ DIO (v/v), and the concentration was $30 \mathrm{mg} \mathrm{mL}^{-1}$. The P3HT:PCBM blend solution was spin coated on the CPN films at $800 \mathrm{rpm}$ for $90 \mathrm{~s}$, which produced a $200 \mathrm{~nm}$ P3HT:PC 61 BM blend layer. $\mathrm{PTB} 7: \mathrm{PC}_{71} \mathrm{BM}$ was blended with the weight ratio of $1: 1.5$ and spin-casted from chlorobenzene with 3\% 1,8-diiodoctane (v/v). The concentration of PTB7 is $10 \mathrm{mg} \mathrm{mL}^{-1}$. The PTB7: $\mathrm{PC}_{71} \mathrm{BM}$ film was prepared from spin coating the blend solution at $1000 \mathrm{rpm} \mathrm{min}^{-1}$ for $120 \mathrm{~s}$. Finally, the substrates were transferred to the vacuum chamber, and $10 \mathrm{~nm} \mathrm{MoO}_{3}$ and $100 \mathrm{~nm}$ Ag were evaporated at $\sim 10^{-6}$ mbar through a shadow mask. The active area of the solar cells was $16 \mathrm{~mm}^{2}$. The thickness of the solution processed films was determined by Bruker DektakXT profilometer. Current density-voltage $(\mathrm{J}-\mathrm{V})$ characteristics of the devices were tested under simulated AM1.5G irradiation from a $300 \mathrm{~W}$ Xe arc lamp set to $100 \mathrm{~mW}$ $\mathrm{cm}^{-2}$ with a calibrated Si photodiode. Electronic characterization was measured by Keithley 2400 source measure unit. The external quantum efficiency (EQE) of the devices was characterized by illumination from a Tunable PowerArc illuminator (Optical Building Blocks 
Corporation). A calibrated photodiode was employed to measure the incident photon number at each wavelength.

\section{Acknowledgements}

The authors would like to thank E. Baudat (ISIC-GE, EPFL) for the solid state NMR measurement, and F. Héroguel and W. Lan (LPDC, EPFL) for FT-IR. The European Research Commission is gratefully acknowledged for financial support of this work (ERC starting grant "CEMOS" Project 336506) and N.G. thanks the Swiss National Foundation (Ambizione Energy Grant, PZENP2_166871).

References

[1] C. Liu, K. Wang, X. Gong, A. J. Heeger, Chem. Soc. Rev. 2016, 45, 4825.

[2] L. Lu, T. Zheng, Q. Wu, A. M. Schneider, D. Zhao, L. Yu, Chem. Rev. 2015, 115, 12666.

[3] O. Knopfmacher, M. L. Hammock, A. L. Appleton, G. Schwartz, J. Mei, T. Lei, J. Pei, Z. Bao, Nat. Commun. 2014, 5, 2954.

[4] J. P. Green, Y. Han, R. Kilmurray, M. A. McLachlan, T. D. Anthopoulos, M. Heeney, Angew. Chem. Int. Ed. 2016, 55, 7148.

[5] G. Kim, S. J. Kang, G. K. Dutta, Y. K. Han, T. J. Shin, Y. Y. Noh, C. Yang, J. Am. Chem. Soc. 2014, 136.

[6] M. M. Obadia, B. P. Mudraboyina, A. Serghei, D. Montarnal, E. Drockenmuller, J. Am. Chem. Soc. 2015, 137, 6078.

[7] E. Blasco, M. Wegener, C. Barner-Kowollik, Adv. Mater. 2017, 29, 1604005.

[8] X. Feng, X. Ding, D. Jiang, Chem. Soc. Rev. 2012, 41, 6010.

[9] F. Vilela, K. Zhang, M. Antonietti, Energy Environ. Sci. 2012, 5, 7819.

[10] J. X. Jiang, F. Su, A. Trewin, C. D. Wood, N. L. Campbell, H. Niu, C. Dickinson, A. Y. Ganin, M. J. Rosseinsky, Y. Z. Khimyak, A. I. Cooper, Angew. Chem. Int. Ed. 2007, 46, 8574 . 
[11] J. Guo, Y. Xu, S. Jin, L. Chen, T. Kaji, Y. Honsho, M. A. Addicoat, J. Kim, A. Saeki, H. Ihee, S. Seki, S. Irle, M. Hiramoto, J. Gao, D. Jiang, Nat. Commun. 2013, 4, 2736.

[12] M. Dogru, M. Handloser, F. Auras, T. Kunz, D. Medina, A. Hartschuh, P. Knochel, T. Bein, Angew. Chem. Int. Ed. 2013, 52, 2920.

[13] M. Calik, F. Auras, L. M. Salonen, K. Bader, I. Grill, M. Handloser, D. D. Medina, M. Dogru, F. Lobermann, D. Trauner, A. Hartschuh, T. Bein, J. Am. Chem. Soc. 2014, $136,17802$.

[14] J. I. Feldblyum, C. H. McCreery, S. C. Andrews, T. Kurosawa, E. J. Santos, V. Duong, L. Fang, A. L. Ayzner, Z. Bao, Chem. Commun. 2015, 51, 13894.

[15] H. Ma, F. Li, P. Li, H. Wang, M. Zhang, G. Zhang, M. Baumgarten, K. Müllen, Adv. Funct. Mater. 2016, 26, 2025.

[16] A. Palma-Cando, U. Scherf, ACS Appl. Mater. Interfaces 2015, 7, 11127.

[17] C. Gu, N. Huang, Y. Chen, H. Zhang, S. Zhang, F. Li, Y. Ma, D. Jiang, Angew. Chem. Int. Ed. 2016, 55, 3049.

[18] C. Gu, N. Huang, Y. Chen, L. Qin, H. Xu, S. Zhang, F. Li, Y. Ma, D. Jiang, Angew. Chem. Int. Ed. 2015, 54, 13594.

[19] C. Gu, Y. Chen, Z. Zhang, S. Xue, S. Sun, K. Zhang, C. Zhong, H. Zhang, Y. Pan, Y. Lv, Y. Yang, F. Li, S. Zhang, F. Huang, Y. Ma, Adv. Mater. 2013, 25, 3443.

[20] M. Li, S. Ishihara, M. Akada, M. Liao, L. Sang, J. P. Hill, V. Krishnan, Y. Ma, K. Ariga, J. Am. Chem. Soc. 2011, 133, 7348 .

[21] D. Becker, N. Heidary, M. Horch, U. Gernert, I. Zebger, J. Schmidt, A. Fischer, A. Thomas, Chem. Commun. 2015, 51, 4283.

[22] C. R. Becer, R. Hoogenboom, U. S. Schubert, Angew. Chem. Int. Ed. 2009, 48, 4900.

[23] J. M. Spruell, M. Wolffs, F. A. Leibfarth, B. C. Stahl, J. Heo, L. A. Connal, J. Hu, C. J. Hawker, J. Am. Chem. Soc. 2011, 133, 16698. 
[24] F. Deng, B. Xu, Y. Gao, Z. Liu, D. Yang, H. Li, J. Polym. Sci., Part A: Polym. Chem. 2012, 50, 3767.

[25] J. Wang, K. Lin, K. Zhang, X.-F. Jiang, K. Mahmood, L. Ying, F. Huang, Y. Cao, Adv. Energy Mater. 2016, 6, 1502563.

[26] C. P. Yau, S. Wang, N. D. Treat, Z. Fei, B. J. Tremolet de Villers, M. L. Chabinyc, M. Heeney, Adv. Energy Mater. 2015, 5, 1401228.

[27] B. J. Kim, Y. Miyamoto, B. Ma, J. M. J. Fréchet, Adv. Funct. Mater. 2009, 19, 2273.

[28] B. Meng, Z. Wang, W. Ma, Z. Xie, J. Liu, L. Wang, Adv. Funct. Mater. 2016, 26, 226.

[29] H. J. Kim, A. R. Han, C.-H. Cho, H. Kang, H.-H. Cho, M. Y. Lee, J. M. J. Fréchet, J. H. Oh, B. J. Kim, Chem. Mater. 2012, 24, 215.

[30] J. W. Rumer, I. McCulloch, Materials Today 2015, 18, 425.

[31] L. Derue, O. Dautel, A. Tournebize, M. Drees, H. Pan, S. Berthumeyrie, B. Pavageau, E. Cloutet, S. Chambon, L. Hirsch, A. Rivaton, P. Hudhomme, A. Facchetti, G. Wantz, Adv. Mater. 2014, 26, 5831.

[32] A. Rahmanudin, X. A. Jeanbourquin, S. Hänni, A. Sekar, E. Ripaud, L. Yao, K. Sivula, J. Mater. Chem. A 2017, DIO:10.1039/c7ta05405j.

[33] X. Zhan, A. Facchetti, S. Barlow, T. J. Marks, M. A. Ratner, M. R. Wasielewski, S. R. Marder, Adv. Mater. 2011, 23, 268.

[34] A. Qin, Y. Liu, B. Z. Tang, Macromol. Chem. Phys. 2015, 216, 818.

[35] L. A. Canalle, S. S. van Berkel, L. T. de Haan, J. C. M. van Hest, Adv. Funct. Mater. 2009, 19, 3464.

[36] C. Huang, S. Barlow, S. R. Marder, J. Org. Chem. 2011, 76, 2386.

[37] K. Nakano, K. Tajima, Adv. Mater. 2017, DOI: 10.1002/adma.201603269.

[38] Y. Wang, X. Zhan, Adv. Energy Mater. 2016, 6, 1600414.

[39] J. Xue, B. P. Rand, S. Uchida, S. R. Forrest, Adv. Mater. 2005, 17, 66. 
[40] X. Xiao, K. J. Bergemann, J. D. Zimmerman, K. Lee, S. R. Forrest, Adv. Energy Mater. 2014, 4, 1301557.

[41] Y. Liang, D. Feng, Y. Wu, S. Tsai, G. Li, C. Ray, L. Yu, J. Am. Chem. Soc. 2009, 131, 7792. 


\section{Supporting Information}

Catalyst-free, Fast and Tunable Synthesis for Robust Covalent Polymer Network Semiconducting Thin Films

Liang Yao, Aiman Rahmanudin, Xavier A. Jeanbourquin, Xiaoyun Yu, Melissa Johnson, Néstor Guijar-ro, Arvindh Sekar, and Kevin Sivula*

[*] Laboratory for Molecular Engineering of Optoelectronic Nanomaterials

École Polytechnique Fédérale de Lausanne (EPFL)

Station 6, 1015 Lausanne, Switzerland

E-mail: kevin.sivula@epfl.ch

\section{Contents}

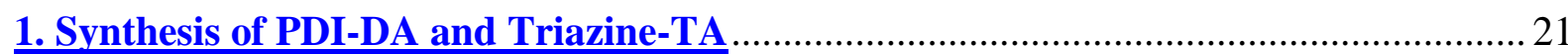

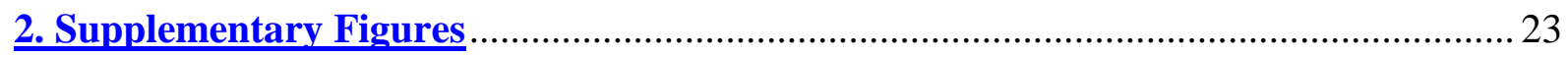

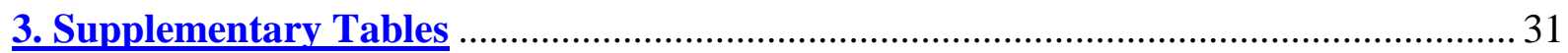




\section{Synthesis of PDI-DA and Triazine-TA}
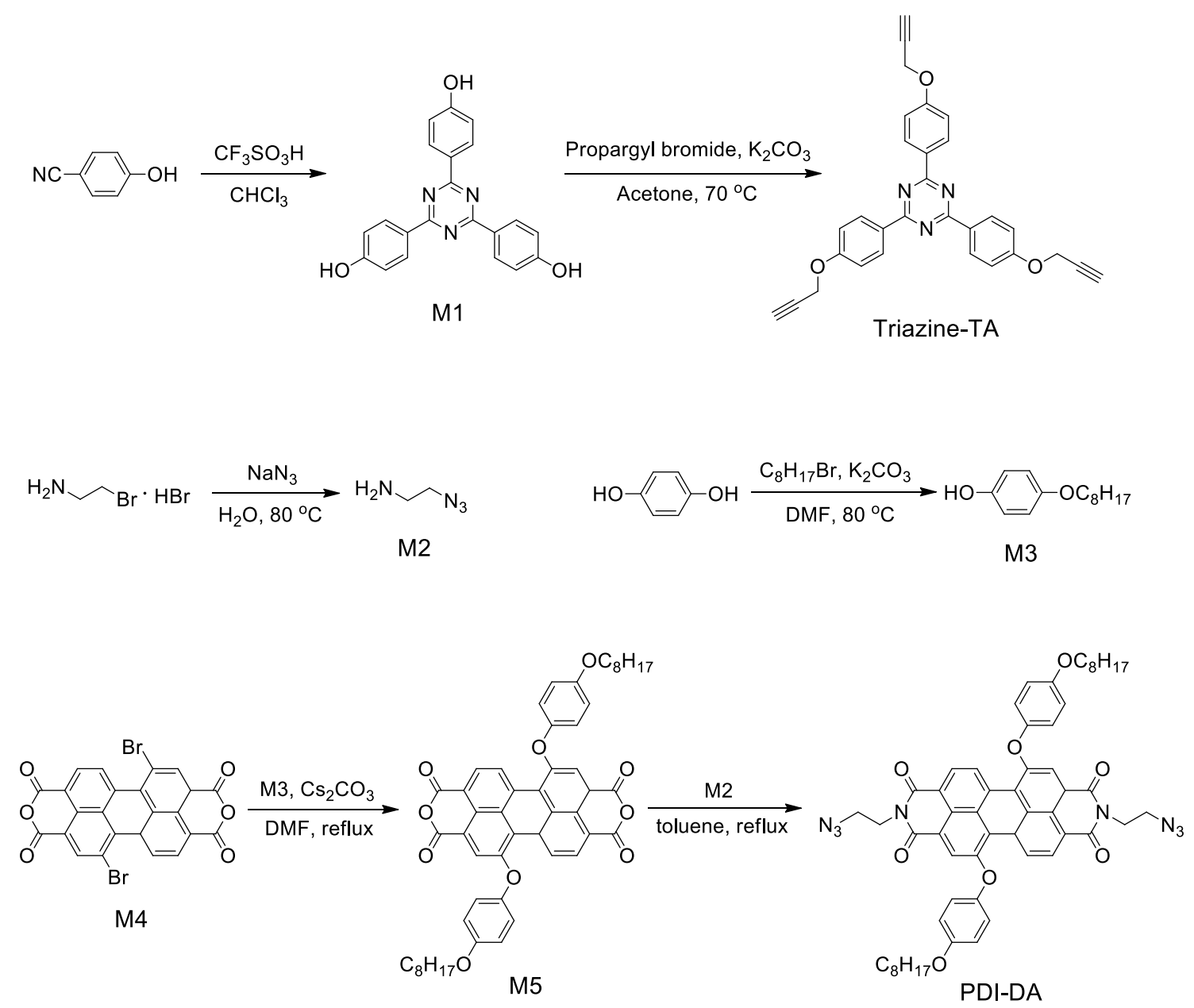

Scheme S1. The synthesis of Triazine-TA and PDI-DA

\section{2,4,6-tris(4-hydroxyphenyl)-1,3,5-triazine (M1)}

4-hydroxybenzonitrile (500 $\mathrm{mg}, 4.2 \mathrm{mmol}$ ) was dissolved in chloroform $(10 \mathrm{~mL})$, and the solution was cooled to $0{ }^{\circ} \mathrm{C}$ by an ice bath. Trifluoromethanesulfonic acid $(1.9 \mathrm{~mL}, 21.0$ mmol) was added dropwise into the stirred solution. After 2 hours, the ice bath was removed and the mixture was continued to stir for 22 hours at room temperature. $20 \mathrm{~mL}$ of water with a small amount of ammonium hydroxide was added into the flask. The organic layer was washed by water for three times, and dried over $\mathrm{MgSO}_{4}$. The crude product was purified by recrystallization from chloroform. White powder was obtained with a yield of $90 \% .{ }^{1} \mathrm{H}$ NMR $\left(400 \mathrm{MHz},\left(\mathrm{CD}_{3}\right)_{2} \mathrm{CO}, 25^{\circ} \mathrm{C}, \mathrm{TMS}\right) \delta=8.68(\mathrm{~d}, J=8.7 \mathrm{~Hz}, 6 \mathrm{H}), 8.03(\mathrm{~s}, 3 \mathrm{H}), 7.06(\mathrm{~d}, J=8.7$ $\mathrm{Hz}, 6 \mathrm{H}) ;{ }^{13} \mathrm{C}$ NMR $\left(100 \mathrm{MHz},\left(\mathrm{CD}_{3}\right)_{2} \mathrm{CO}, 2{ }^{\circ} \mathrm{C}\right.$, TMS $) \delta=170.71,161.61,130.82,127.88$, 115.44. MALDI-TOF MS (mass m/z): $358.2\left[\mathrm{M}^{+}\right]$.

\section{2,4,6-tris(4-(prop-2-yn-1-yloxy)phenyl)-1,3,5-triazine (Triazine-TA)}

M1 (1.5 g, $4.2 \mathrm{mmol})$, propargyl bromide $\left(9.2 \mathrm{~mol} \mathrm{~L}^{-1}\right.$ in toluene, $\left.2.06 \mathrm{~mL}, 19.0 \mathrm{mmol}\right)$, potassium carbonate $(8.7 \mathrm{~g}, 62.3 \mathrm{mmol})$ and $60 \mathrm{~mL}$ of acetone were placed in a $250 \mathrm{~mL}$ round bottom flask. The mixture was heated to reflux for 1 day while stirring. After that, the reaction mixture was cooled down to room temperature and washed by water/dichloromethane. The organic layer was collected, dried over $\mathrm{MgSO}_{4}$, and concentrated by rotavapor. The crude 
product was purified through silica gel chromatography using hexane/dichloromethane $(1: 1)$ as eluent. The desired compound was obtained as white powder in the yield of $51 \% .{ }^{1} \mathrm{H}$ NMR $\left(400 \mathrm{MHz}, \mathrm{CDCl}_{3}, 25^{\circ} \mathrm{C}, \mathrm{TMS}\right) \delta=8.75(\mathrm{~d}, J=8.8 \mathrm{~Hz}, 6 \mathrm{H}), 7.16(\mathrm{~d}, J=8.8 \mathrm{~Hz}, 6 \mathrm{H}), 4.84(\mathrm{~s}$, $6 \mathrm{H}), 2.60(\mathrm{~s}, 3 \mathrm{H}) ;{ }^{13} \mathrm{C} \mathrm{NMR}\left(100 \mathrm{MHz}, \mathrm{CDCl}_{3}, 25{ }^{\circ} \mathrm{C}, \mathrm{TMS}\right) \delta=170.71,161.02,130.71$, 129.90, 114.79, 78.12, 75.96, 55.91. MALDI-TOF MS (mass m/z): $472.3\left[\mathrm{M}^{+}\right]$.

\section{2-azidoethanamine (M2)}

Sodium azide (1.36 g, $22.2 \mathrm{mmol})$ was dissolved in $6 \mathrm{~mL}$ of water. 2-Bromoethylamine hydrobromide ( $1.43 \mathrm{~g}, 7 \mathrm{mmol})$ was added in the solution. The reaction mixture was heated to $75{ }^{\circ} \mathrm{C}$ for 24 hours. After that, the solution was cooled down to $0{ }^{\circ} \mathrm{C}$ by an ice bath and potassium hydroxide (about $700 \mathrm{mg}$ ) added. The product was extracted by diethyl ether (20 $\mathrm{mL}$ ) for four times. Since 2-Azidoethanamine is highly volatile and possible to cause explosion, diethyl ether was evaporated in fume hood at room temperature. Colorless oil was obtained with a yield of $85 \%$, and used for further reaction without storage. ${ }^{1} \mathrm{H}$ NMR (400 $\left.\mathrm{MHz}, \mathrm{CDCl}_{3}, 25^{\circ} \mathrm{C}, \mathrm{TMS}\right) \delta=3.40(\mathrm{t}, J=5.6 \mathrm{~Hz}, 2 \mathrm{H}), 2.92(\mathrm{t}, J=5.7 \mathrm{~Hz}, 2 \mathrm{H}), 1.44(\mathrm{~s}, 2 \mathrm{H})$; ${ }^{13} \mathrm{C}$ NMR $\left(100 \mathrm{MHz}, \mathrm{CDCl}_{3}, 25{ }^{\circ} \mathrm{C}, \mathrm{TMS}\right) \delta=54.75,41.43$.

\section{4-(octyloxy)phenol (M3)}

Hydroquinone $(9.9 \mathrm{~g}, 0.09 \mathrm{~mol}), 1$-bromooctane $(5.79 \mathrm{~g}, 0.03 \mathrm{~mol})$, potassium carbonate $(12.4$ $\mathrm{g}, 0.09 \mathrm{~mol}$ ) and $60 \mathrm{~mL}$ of DMF were placed in a $250 \mathrm{~mL}$ round bottom flask. The mixture was heated at $80{ }^{\circ} \mathrm{C}$ for 24 hours. After the reaction is finished, the crude product was extracted by ethyl acetate and 10\% (v/v) diluted hydrochloric acid, and purified by silica chromatography (dichloromethane:hexane $=1: 1$ ). Pale powder was obtained with a yield of 61\%. ${ }^{1} \mathrm{H}$ NMR (400 MHz, DMSO, $25{ }^{\circ} \mathrm{C}$, TMS $) \delta=8.88(\mathrm{~s}, 1 \mathrm{H}), 6.69(\mathrm{~m}, 4 \mathrm{H}), 3.82(\mathrm{~m}, 2 \mathrm{H})$; $1.66(\mathrm{~m}, 2 \mathrm{H}), 1.35(\mathrm{~m}, 10 \mathrm{H}), 0.87(\mathrm{~m}, 3 \mathrm{H}) ;{ }^{13} \mathrm{C} \mathrm{NMR}\left(100 \mathrm{MHz}, \mathrm{CDCl}_{3}, 25{ }^{\circ} \mathrm{C}, \mathrm{TMS}\right) \delta=$ $153.38,149.32,115.99,115.64,68.76,31.84,29.40,29.26,26.07,22.68,14.12$.

N,N'-di(2-azidoethyl)-1,7-di(4-tert-butylphenoxy)perylene-3,4:9,10-tetracarboxylic acid bisimide (PDI-DA)

1,7-Dibromoperylene-3,4:9,10-tetracarboxylic acid bisanhydride (M4) was synthesized according to literatures (F. Würthner, etal , J. Org. Chem. 2004, 69, 7933-7939). The mixture of M4 (1.37 g, $2.5 \mathrm{mmol}), \mathrm{M} 3(2.22 \mathrm{~g}, 10 \mathrm{mmol}), \mathrm{Cs}_{2} \mathrm{CO}_{3}(1.63 \mathrm{~g}, 5 \mathrm{mmol})$ were suspended in $30 \mathrm{~mL}$ of DMF. The solution was heated at refluxing temperature for 4 hours under argon atmosphere. After cooling to room temperature, $100 \mathrm{~mL}$ of $10 \%(\mathrm{v} / \mathrm{v})$ diluted hydrochloric acid was poured into the reaction solution. The precipitation was collected by filtration, and washed by water and methanol. Since the crude (1,7-di(4-(octyloxy)phenoxy)perylene3,4:9,10-tetracarboxylic acid bisanhydride, M5) shows a poor solubility in common solvents, it is directly used for next reaction without purification and characterization. The yield of the crude product is $90 \%$.

M5 (970 mg, $1.16 \mathrm{mmol})$, M2 (500 mg, $5.81 \mathrm{mmol})$ and $40 \mathrm{~mL}$ of toluene were stirred at reflux temperature under argon atmosphere for 24 hours. After the reaction is completed, the toluene was evaporated by rotavapor. The crude product was purified by silica chromatography (dichloromethane:hexane $=1: 1)$, yielding $338 \mathrm{mg}(30 \%)$ of PDI-DA as black powder. ${ }^{1} \mathrm{H}$ NMR $\left(400 \mathrm{MHz}, \mathrm{CDCl}_{3}, 25{ }^{\circ} \mathrm{C}\right.$, TMS $) \delta=9.70(\mathrm{~d}, J=8.4 \mathrm{~Hz}, 2 \mathrm{H}), 8.68(\mathrm{~d}, J=$ $8.4 \mathrm{~Hz}, 2 \mathrm{H}), 8.36(\mathrm{~s}, 2 \mathrm{H}), 7.14(\mathrm{~d}, J=8.9 \mathrm{~Hz}, 4 \mathrm{H}), 7.02(\mathrm{~d}, J=8.9 \mathrm{~Hz}, 4 \mathrm{H}), 4.45(\mathrm{~m}, 4 \mathrm{H})$, $4.03(\mathrm{~m}, 4 \mathrm{H}), 3.70(\mathrm{~m}, 4 \mathrm{H}), 1.86(\mathrm{~m}, 4 \mathrm{H}), 1.36(\mathrm{~m}, 20 \mathrm{H}), 0.94(\mathrm{~m}, 6 \mathrm{H}) ;{ }^{13} \mathrm{C}$ NMR $(100 \mathrm{MHz}$, $\mathrm{CDCl}_{3}, 25{ }^{\circ} \mathrm{C}$, TMS) $\delta=163.38,163.04,156.95,156.88,156.39,147.88,133.76,130.29$, 129.30, 128.96, 124.78, 123.25, 123.06, 121.67, 121.19, 116.29, 68.64, 48.83, 39.02, 31.85, 29.39, 29.31, 29.28, 26.10, 22.70, 14.14. MALDI-TOF MS (mass m/z): $970.1\left[\mathrm{M}^{+}\right]$. 


\section{Supplementary Figures}
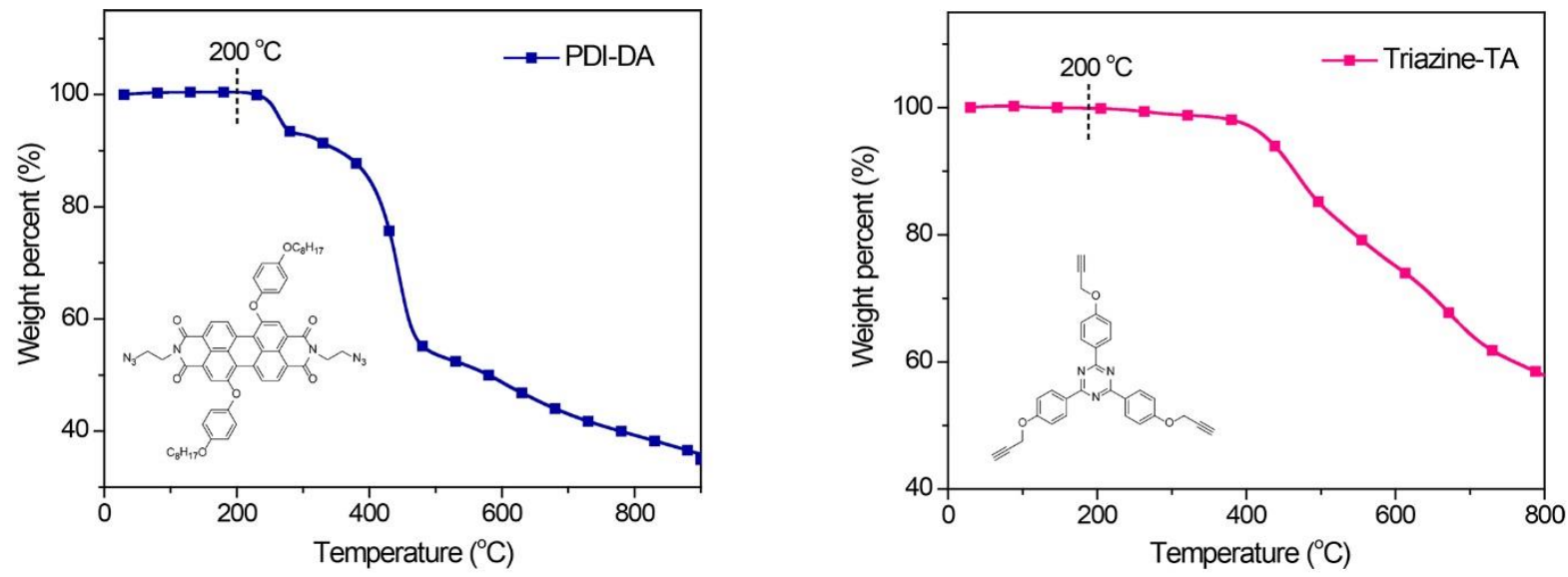

Figure S1. TGA curve of PDI-DA and Triazine-TA
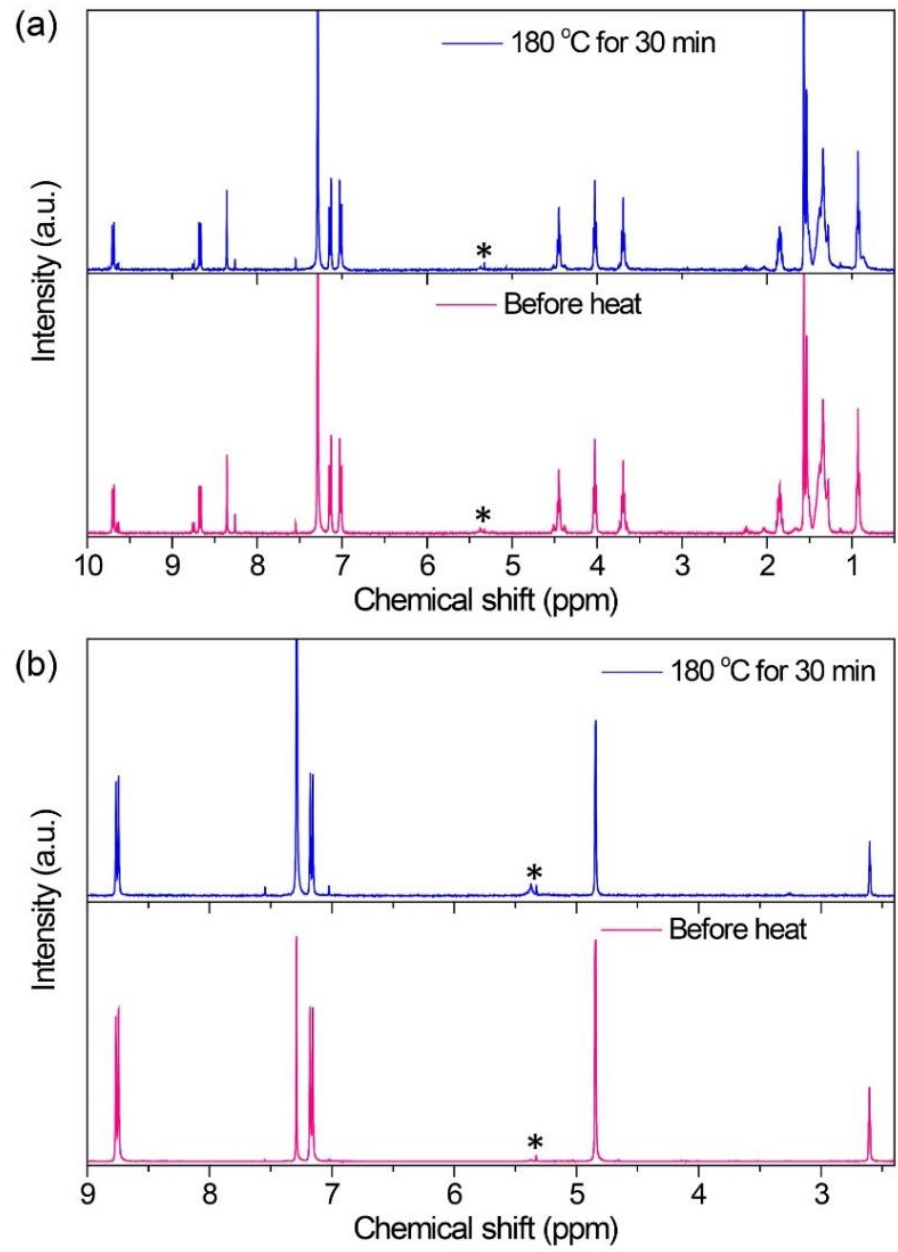

Figure S2. ${ }^{1} \mathrm{H}$ NMR spectra of (a) PDI-DA and (b) Triazine-TA before and after heating at $180{ }^{\circ} \mathrm{C}$ for $30 \mathrm{~min}$. The star label in the figure represents solvent signal. 


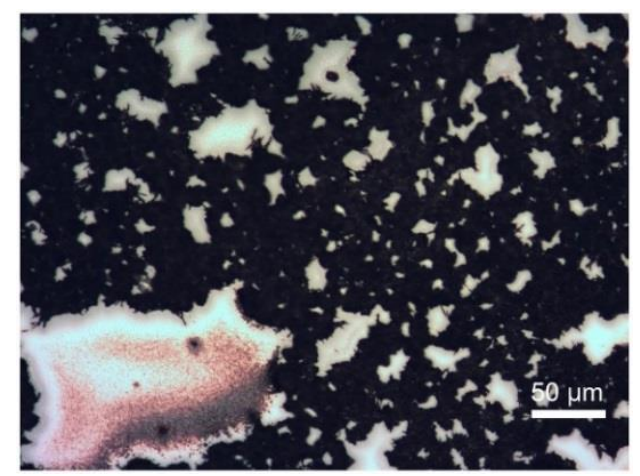

Figure S3. Optical microscope image of the blend film prepared from solvent evaporation. The blend of $5 \mathrm{mg}$ PDI-DA and $1.62 \mathrm{mg}$ Triazine-TA was dissolved in $1 \mathrm{~mL}$ chloroform.

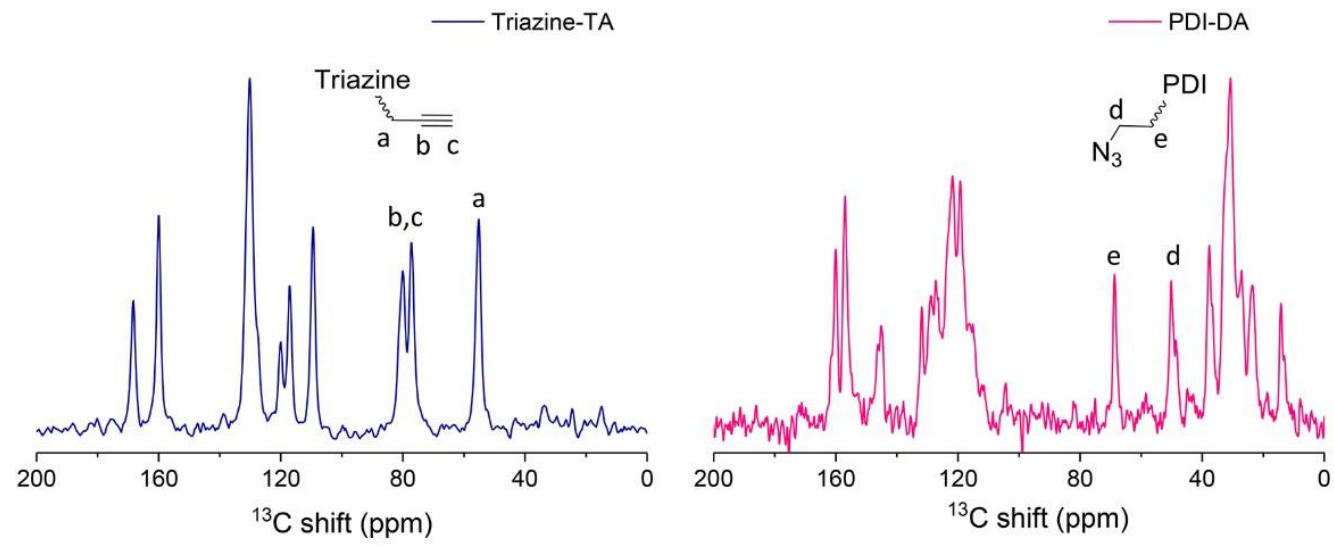

Figure S4. ${ }^{13} \mathrm{C}$ solid-state MAS-NMR of Triazine-TA and PDI-DA.

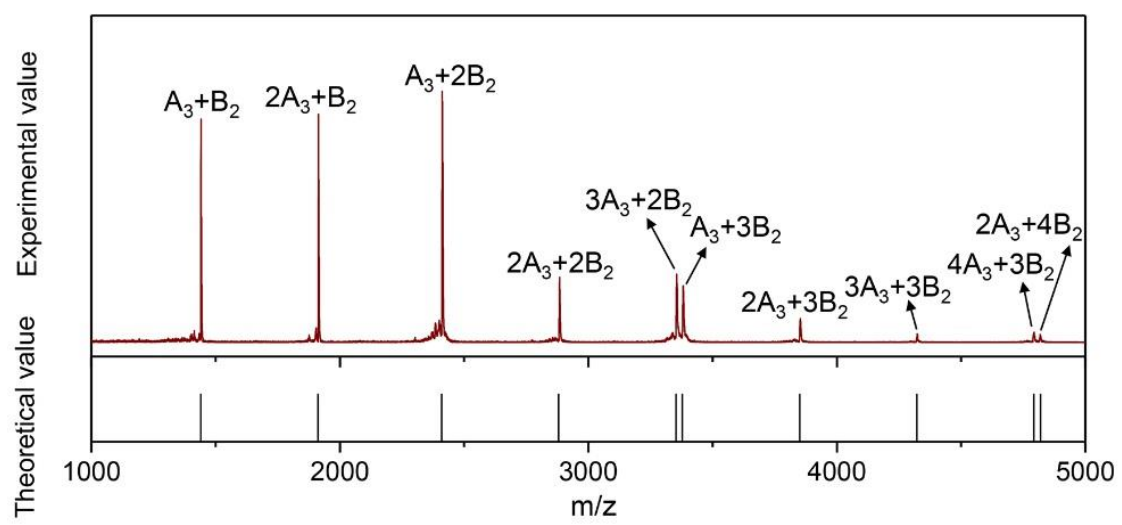

Figure S5. Mass spectra of the soluble products obtained by the in-situ TAAC reaction. The top figure shows the experimental results, and the bottom figure gives the theoretical values. The solid state mixture of PDI-DA and Triazine-TA was heated at $180{ }^{\circ} \mathrm{C}$ for $1 \mathrm{~h}$. After the reaction, the soluble products were extracted by chloroform. $A_{3}$ and $B_{2}$ in the figure represents Triazine-TA and PDI-DA, respectively. 

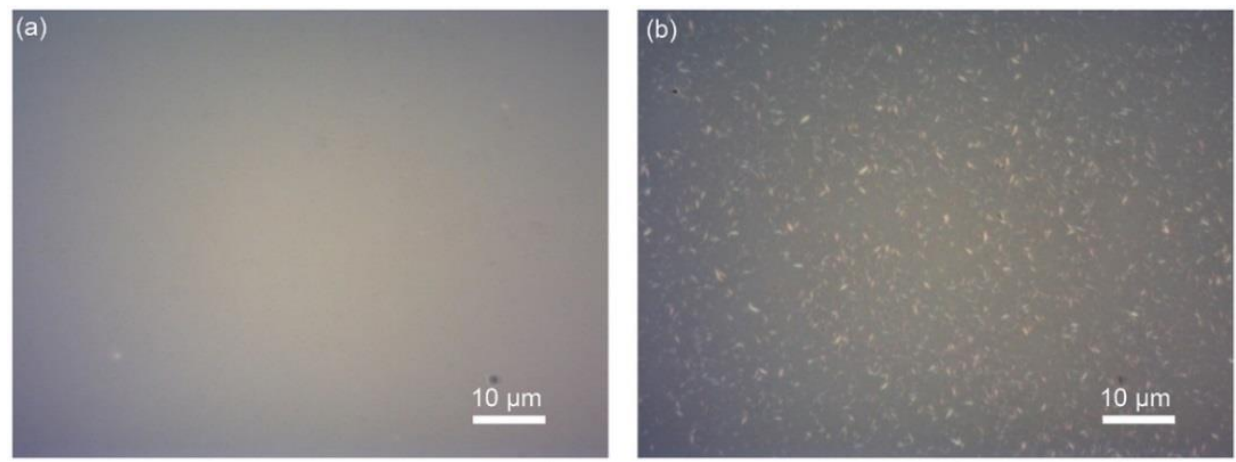

Figure S6. Optical microscope images of the spin-coating films (35 nm). (a) Chloroform as processing solvent; (b) chlorobenzene as processing solvent. The blend solution of $3 \mathrm{mg} \mathrm{mL}^{-1}$ PDI-DA and $0.97 \mathrm{mg} \mathrm{mL}^{-1}$ Triazine-TA dissolved in chloroform or chlorobenzene was spin coated on glass substrate. Chloroform enables a smooth and homogenous film (Figure S6a). Micrometer-scale phase segregation was observed in the film processed from chlorobenzene solution (Figure S6b), which is induced by the slow evaporation of chlorobenzene.

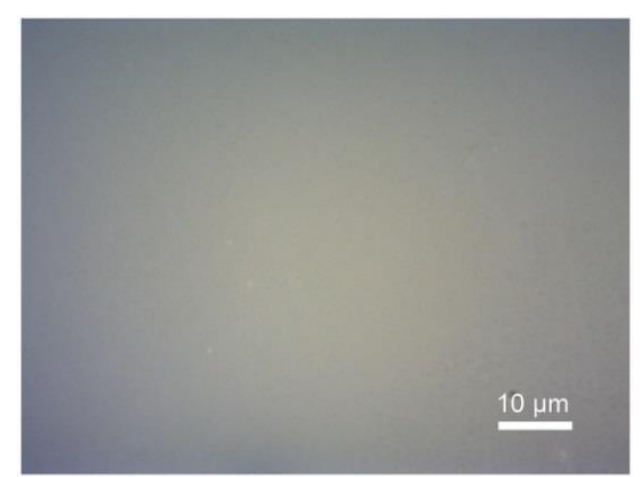

Figure S7. Optical microscope image of the PDI-DA and Triazine-TA blend film after heating at $180{ }^{\circ} \mathrm{C}$ for $30 \mathrm{~min}$. The smooth morphology is still kept after heating.
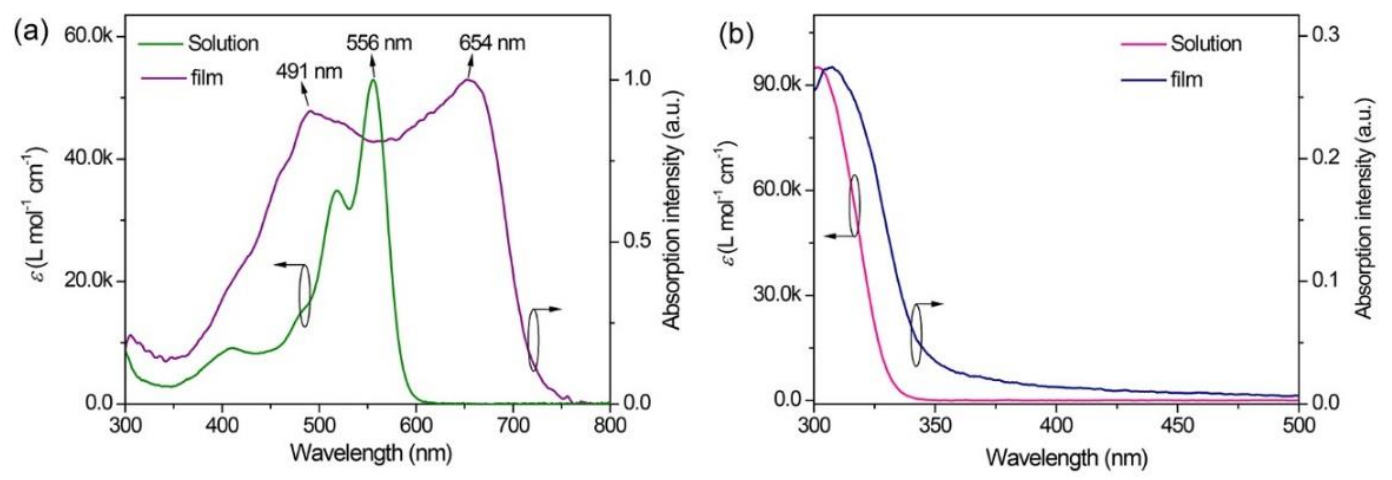

Figure S8. (a) Absorption spectra of PDI-DA in thin film and solution. (b) Absorption spectra of Triazine-TA in thin film and solution. PDI-DA exhibits a sharp absorption with the peak at 
$556 \mathrm{~nm}$ in diluted solution $\left(10^{-5} \mathrm{~mol} \mathrm{~L} \mathrm{~L}^{-1}\right.$ in THF). In thin film, the absorption spectra is broadened, and the absorption peak is shifted to $654 \mathrm{~nm}$ and $491 \mathrm{~nm}$, which is caused by the $\pi-\pi$ stacking of PDI-DA. The UV spectra of Triazine-TA show the maximum absorption peak at $305 \mathrm{~nm}$, indicating that Triazine-TA has a very wide band-gap.
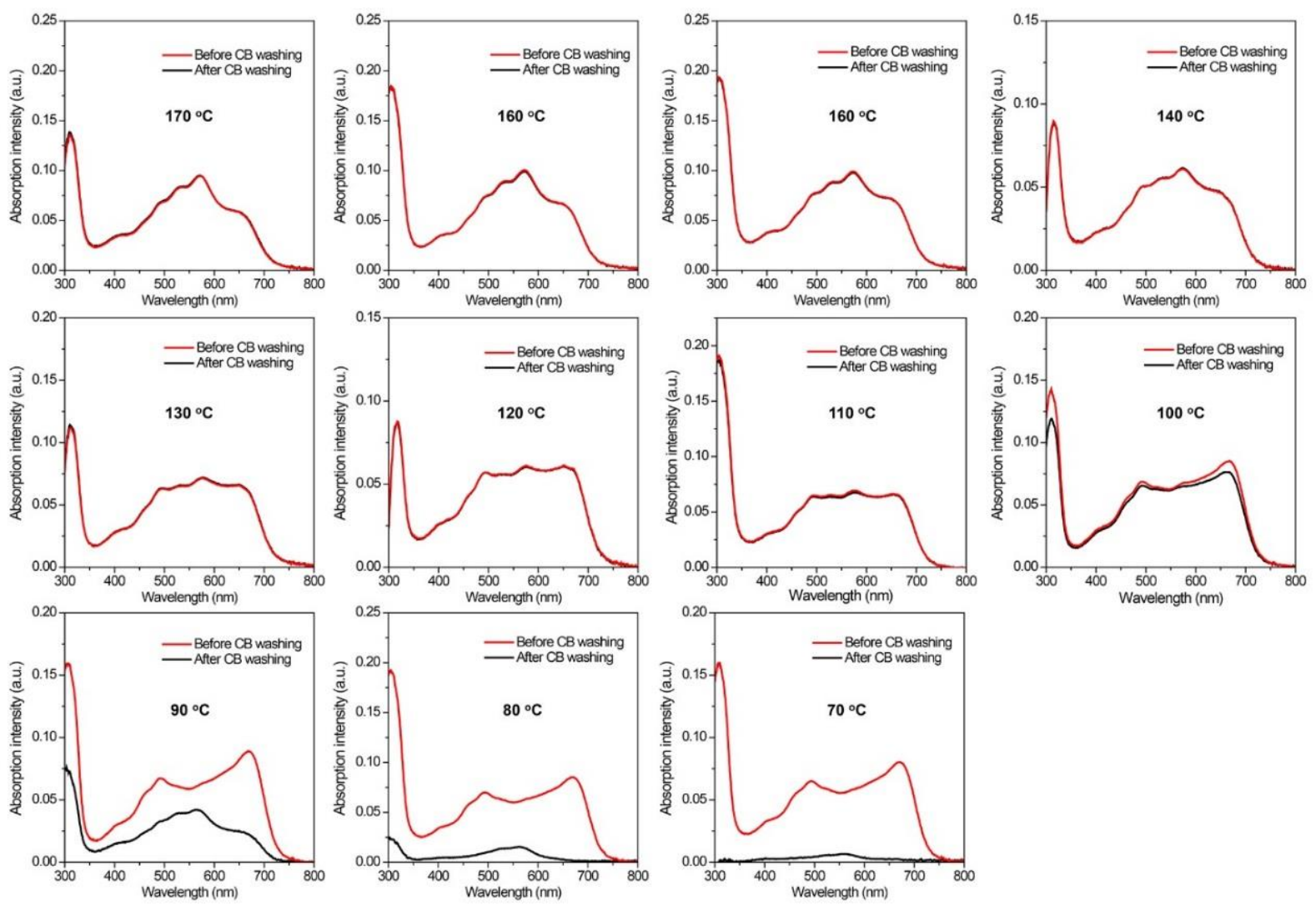

Figure S9. UV spectra of the polymer network films before and after washing by chlorobenzene (CB). Different heating temperatures are compared. The heating time for all the films was 10 mins. It can be seen that for the films heated at the temperature higher than $120{ }^{\circ} \mathrm{C}$, the absorption keeps the same after washing by $\mathrm{CB}$. The result implies that appreciable reaction extent can be achieved at the heating temperature higher than $120{ }^{\circ} \mathrm{C}$. 


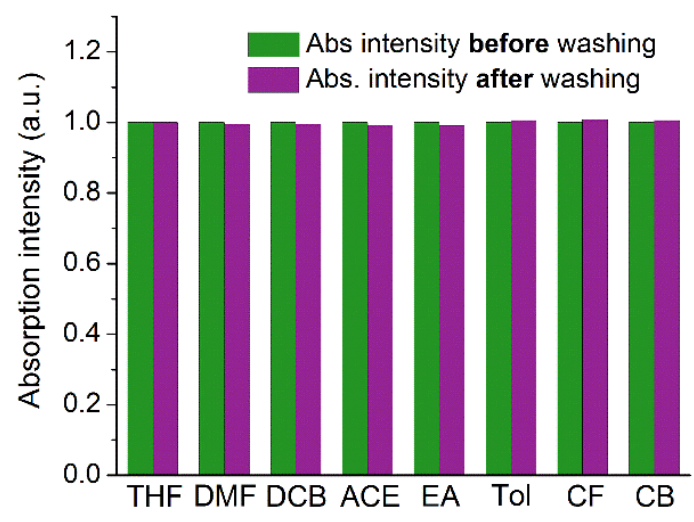

Figure S10. The resistance of the CPN film for common organic solvents. The CPN film was prepared from heating the blend film at $180{ }^{\circ} \mathrm{C}$ for $10 \mathrm{~min}$. THF: tetrahydrofuran, DMF: dimethylformamide, DCB: dichlorobenzene, ACE: acetonitrile, EA: ethyl acetate, Tol: toluene, $\mathrm{CF}$ : chloroform, $\mathrm{CB}$ : chlorobenzene.

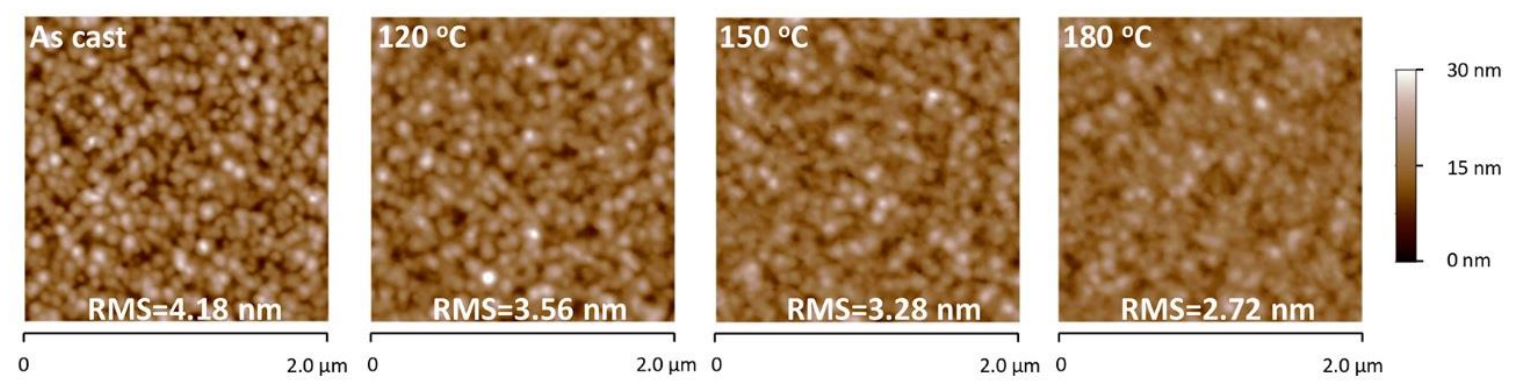

Figure S11. Atomic force microscopy (AFM) images of the as cast film and the films heated at different temperature for $10 \mathrm{~min}$.
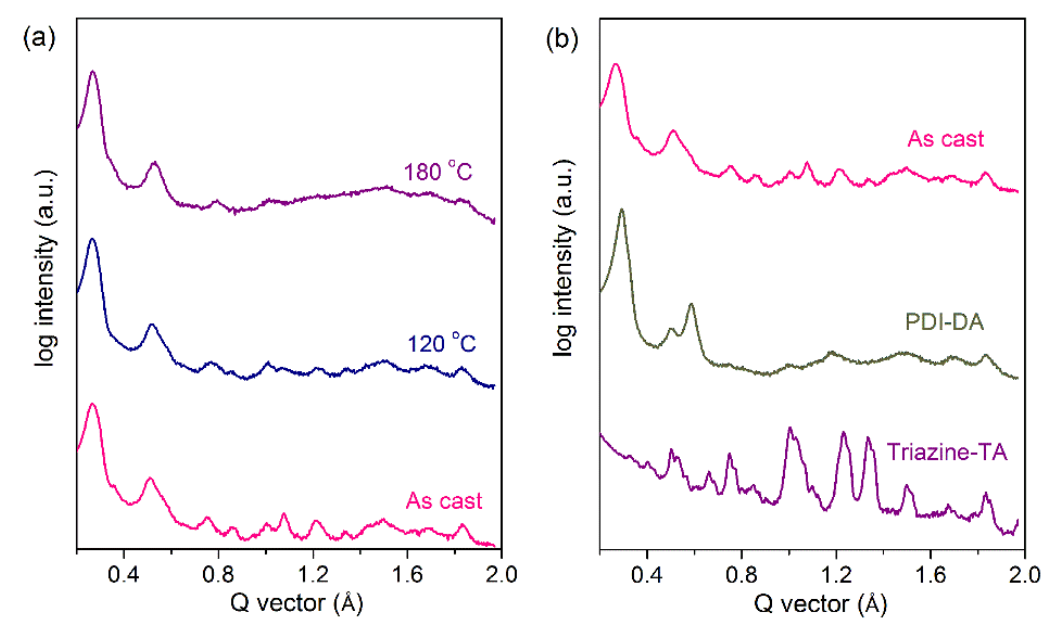

Figure S12. (a) GIWAXS out-of-plane line-cuts of as cast film and heated films $\left(120{ }^{\circ} \mathrm{C}\right.$ or $180{ }^{\circ} \mathrm{C}$ ). (b) GIWAXS out-of-plane line-cuts of as cast film, PDI-DA and Triazine-TA. The blend film was prepared by drop casting. The as cast blend film contained the scattering peaks of both PDI-DA and Triazine-TA. After heating, it can be observed that some peaks are less pronounced. The heating time for the TAAC reaction was $30 \mathrm{~min}$. 


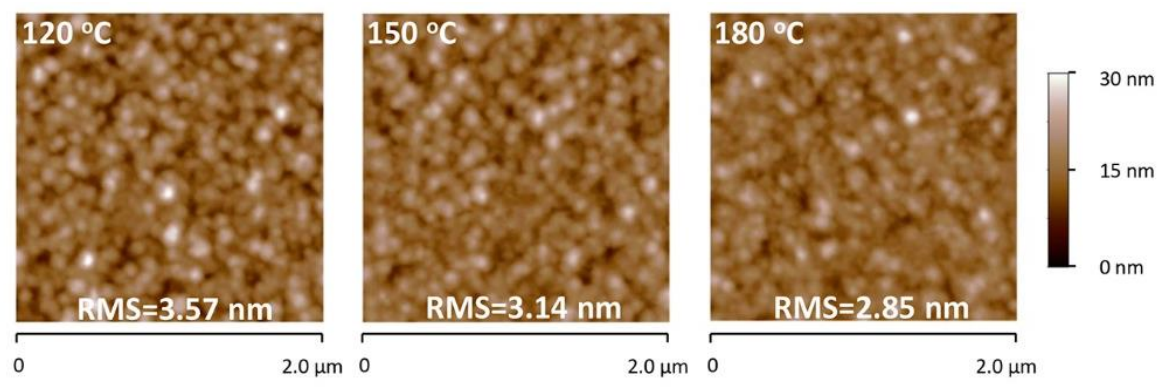

Figure S13. AFM images of the films heated at different temperature for 2 hours.

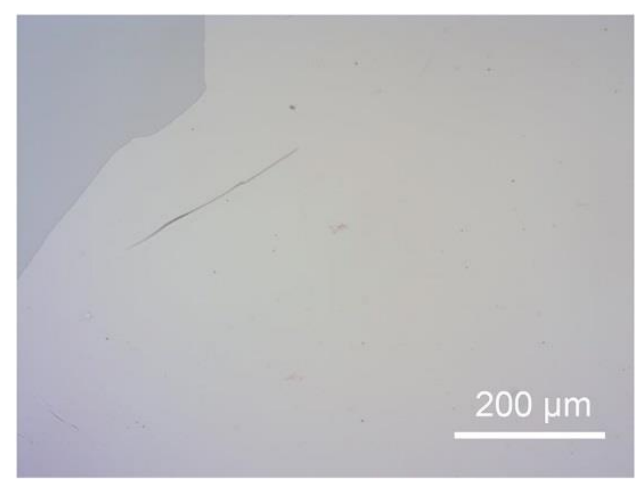

Figure S14. Optical microscope image of the free-standing CPN film supported by a glass substrate. The scale bar is $200 \mu \mathrm{m}$.
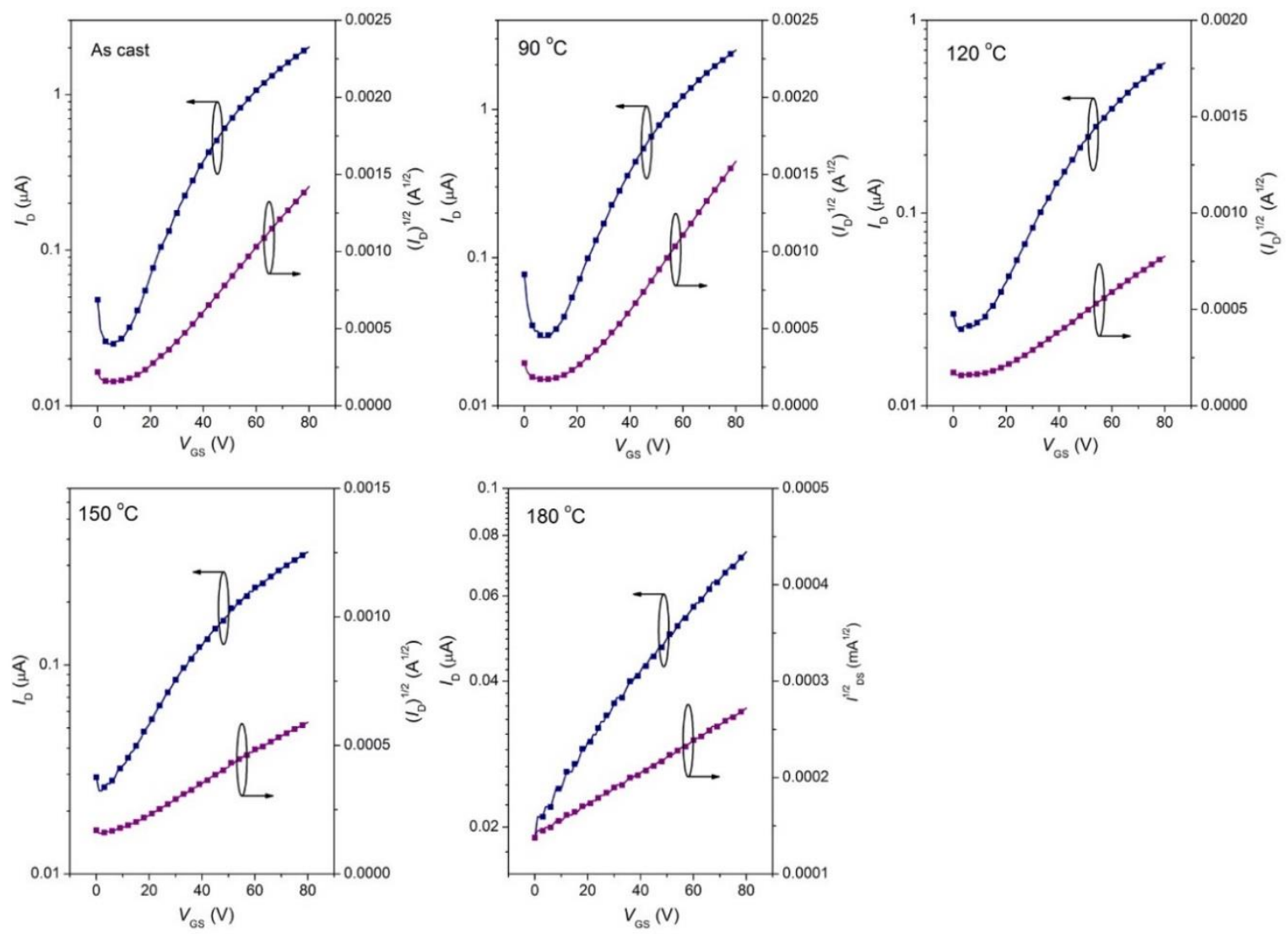

Figure S15. Transfer curves of the transistors. The heating time was $10 \mathrm{~min}$. The $V_{\mathrm{D}}$ of $80 \mathrm{~V}$ was applied. 

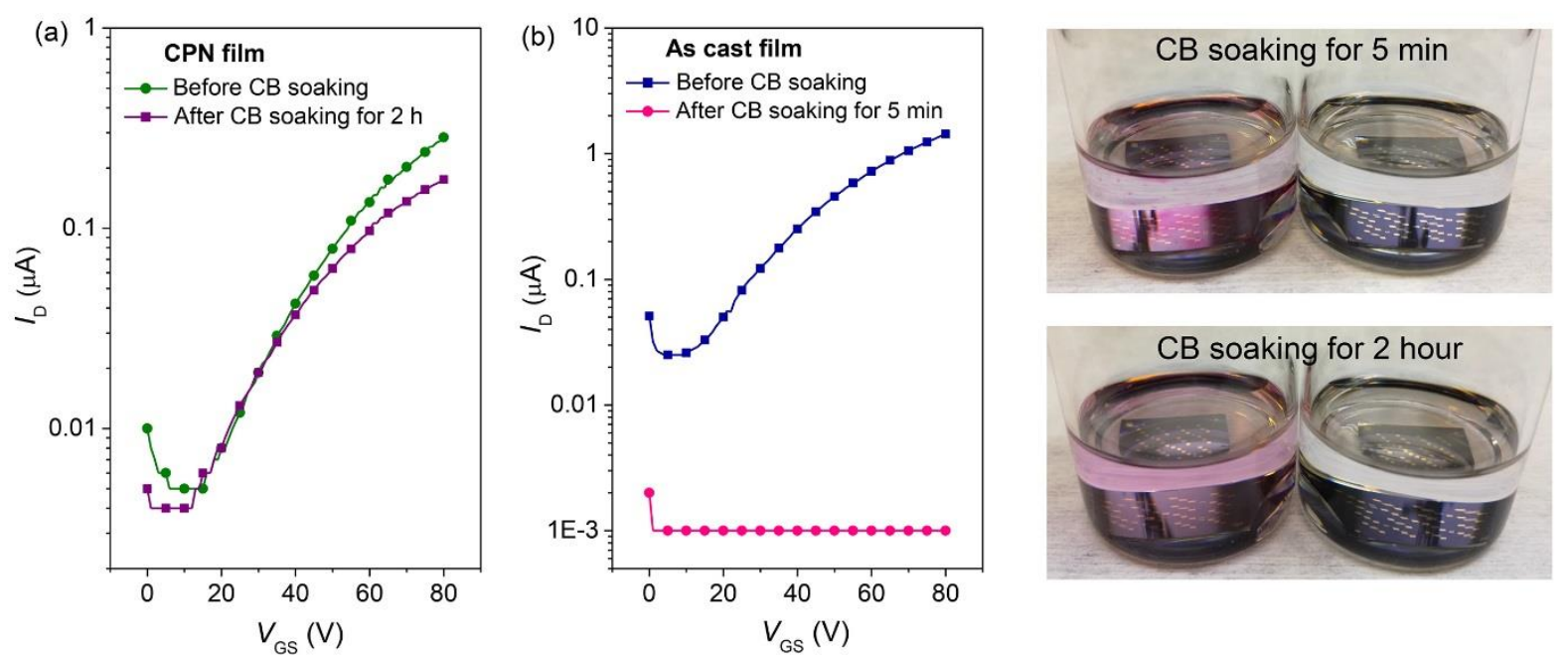

Figure S16. Transfer curve of the transistors. (a) CPN film transistor before and after 2 hour CB soaking, (b) as cast film transistor before and after 5 min CB soaking. CPN film is obtained after heating at $150{ }^{\circ} \mathrm{C}$ for $10 \mathrm{~min}$. The $V_{\mathrm{D}}$ of $80 \mathrm{~V}$ was applied.

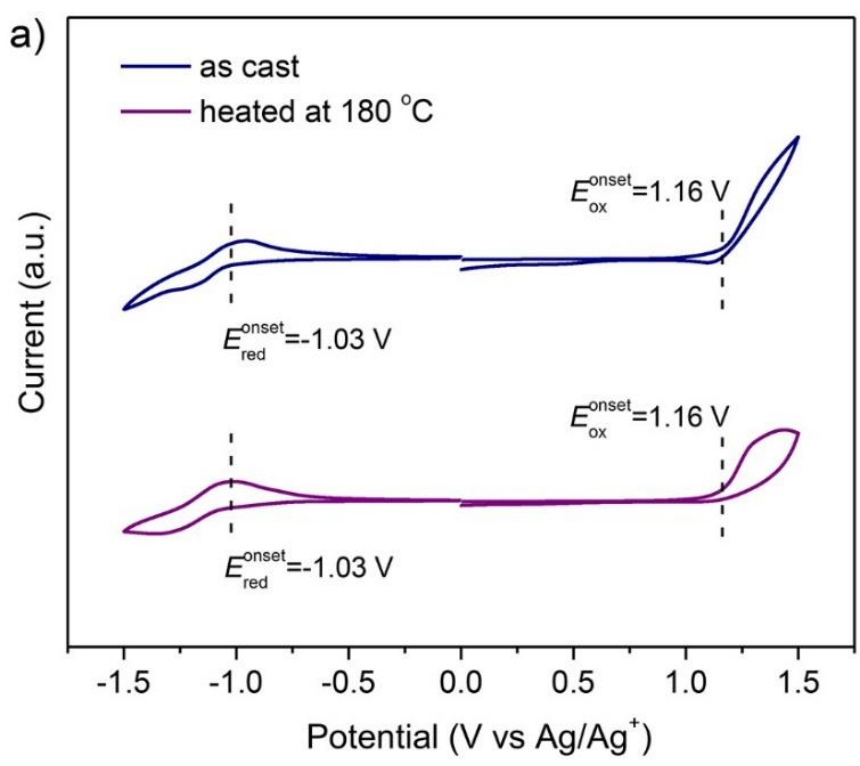

b)

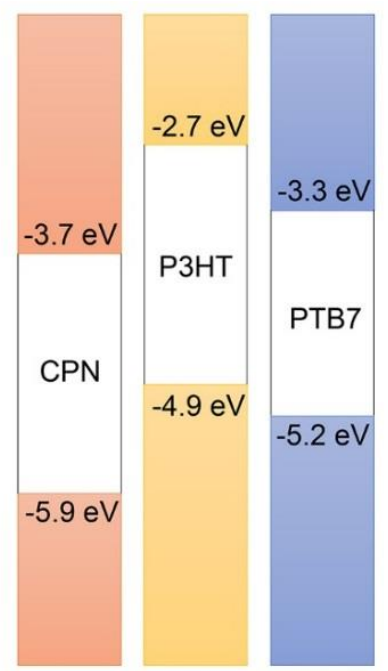

Figure S17. a) CV curve of the PDI-DA and Triazine-TA blend. The film after heating at 180 ${ }^{\circ} \mathrm{C}$ for 20 min exhibits the identical onset reduction and oxidation potential with the as cast film. The HOMO and LUMO levels are estimated as $-5.9 \mathrm{eV}$ and $-3.7 \mathrm{eV}$, respectively. The result indicates the heating temperature of TAAC reaction has insignificant effect on the energy levels of the films. b) Energy level alignment of CPN, P3HT and PTB7. 

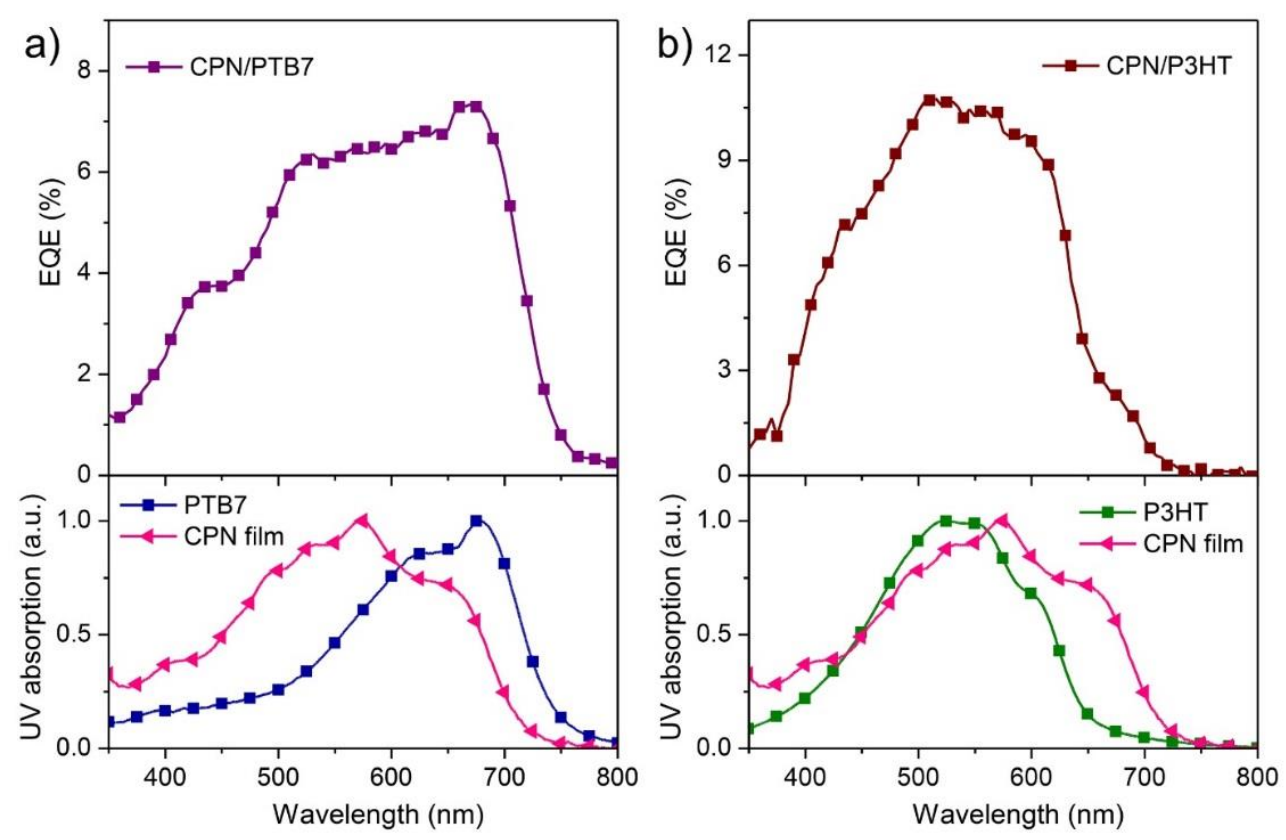

Figure S18. The EQE curve of the optimal a) CPN/PTB7 and b) CPN/P3HT PHJ devices. The bottom figure shows the absorption spectra of PTB7, P3HT and CPN film. The CPN film was prepared from heating at $150{ }^{\circ} \mathrm{C}$ for $10 \mathrm{~min}$.
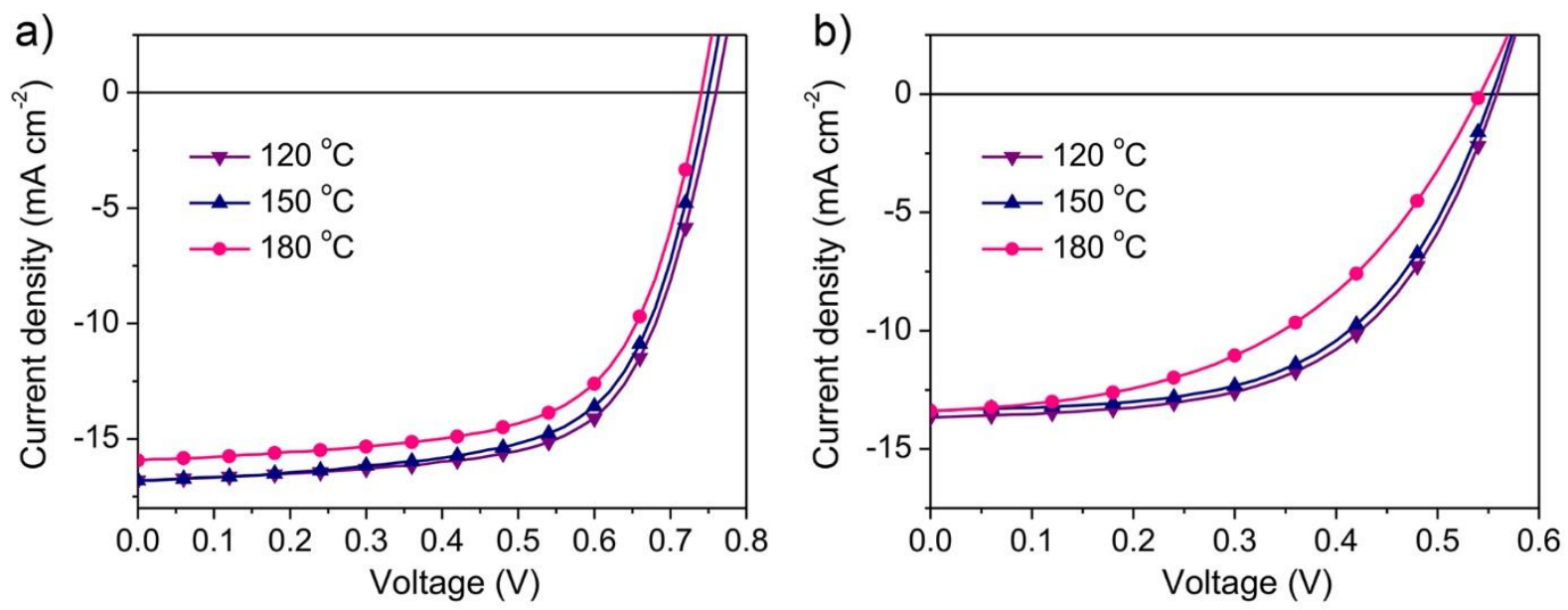

Figure S19. $J-V$ characteristics of a) CPN/PTB7:PC ${ }_{71} \mathrm{BM}$ and b) CPN/P3HT:PC ${ }_{61} \mathrm{BM} \mathrm{PM}-\mathrm{HJ}$ devices. 


\section{Supplementary Tables}

Table S1. The average electron motilities calculated from 4 transistors.

1) $\mathrm{T}_{\mathrm{rxn}}=90^{\circ} \mathrm{C}$

\begin{tabular}{|c|c|c|c|c|c|}
\hline Heating time & $10 \mathrm{~min}$ & $30 \mathrm{~min}$ & $60 \mathrm{~min}$ & $90 \min$ & $120 \mathrm{~min}$ \\
\hline $\begin{array}{c}\text { Mobility } \\
\left(\mathrm{cm}^{2} \mathrm{~V}^{-1} \mathrm{~s}^{-1}\right)\end{array}$ & $(1.6 \pm 0.4) \times 10^{-5}$ & $(1.4 \pm 0.3) \times 10^{-5}$ & $(1.0 \pm 0.2) \times 10^{-5}$ & $(1.1 \pm 0.2) \times 10^{-5}$ & $(1.8 \pm 0.8) \times 10^{-5}$ \\
\hline \multicolumn{6}{|l|}{ 2) $\mathrm{T}_{\mathrm{rxn}}=120^{\circ} \mathrm{C}$} \\
\hline Heating time & $10 \mathrm{~min}$ & $30 \mathrm{~min}$ & $60 \mathrm{~min}$ & $90 \mathrm{~min}$ & $120 \mathrm{~min}$ \\
\hline $\begin{array}{c}\text { Mobility } \\
\left(\mathrm{cm}^{2} \mathrm{~V}^{-1} \mathrm{~s}^{-1}\right)\end{array}$ & $(5.1 \pm 0.9) \times 10^{-6}$ & $(3.7 \pm 0.8) \times 10^{-6}$ & $(3.2 \pm 0.7) \times 10^{-6}$ & $(3.1 \pm 0.7) \times 10^{-6}$ & $(3.1 \pm 0.6) \times 10^{-6}$ \\
\hline \multicolumn{6}{|l|}{ 3) $\mathrm{T}_{\mathrm{rxn}}=150^{\circ} \mathrm{C}$} \\
\hline Heating time & $10 \mathrm{~min}$ & $30 \mathrm{~min}$ & $60 \mathrm{~min}$ & $90 \mathrm{~min}$ & $120 \mathrm{~min}$ \\
\hline $\begin{array}{c}\text { Mobility } \\
\left(\mathrm{cm}^{2} \mathrm{~V}^{-1} \mathrm{~s}^{-1}\right)\end{array}$ & $(1.4 \pm 0.09) \times 10^{-6}$ & $(2.1 \pm 0.08) \times 10^{-6}$ & $(1.2 \pm 0.03) \times 10^{-6}$ & $(1.3 \pm 0.06) \times 10^{-6}$ & $1.3 \times 10^{-6}$ \\
\hline \multicolumn{6}{|l|}{ 4) $\mathrm{T}_{\mathrm{rxn}}=180^{\circ} \mathrm{C}$} \\
\hline Heating time & $10 \mathrm{~min}$ & $30 \mathrm{~min}$ & $60 \mathrm{~min}$ & $90 \mathrm{~min}$ & $120 \mathrm{~min}$ \\
\hline $\begin{array}{c}\text { Mobility } \\
\left(\mathrm{cm}^{2} \mathrm{~V}^{-1} \mathrm{~s}^{-1}\right)\end{array}$ & $(9.0 \pm 0.4) \times 10^{-8}$ & $(7.8 \pm 0.5) \times 10^{-8}$ & $(8.7 \pm 0.5) \times 10^{-8}$ & $(7.7 \pm 0.5) \times 10^{-8}$ & $(11.1 \pm 0.5) \times 10^{-8}$ \\
\hline
\end{tabular}

Table S2. Photovoltaic parameters of the PHJ devices. The results are average values calculated from 6 cells.

\begin{tabular}{cccccccc}
\hline $\begin{array}{c}\text { CPN film } \\
\text { thickness }\end{array}$ & $\mathrm{T}_{\text {rxn }}$ & Polymer & $\begin{array}{c}\text { Polymer } \\
\text { thickness }\end{array}$ & $\begin{array}{c}V_{\text {oc }} \\
{[\mathrm{V}]}\end{array}$ & $\begin{array}{c}J_{\mathrm{sc}} \\
{\left[\mathrm{mA} \mathrm{cm}{ }^{-2}\right]}\end{array}$ & FF & $\begin{array}{c}\text { PCE }_{\text {avg(max })} \\
{[\%]}\end{array}$ \\
\hline $0 \mathrm{~nm}$ & ---- & P3HT & $60 \mathrm{~nm}$ & 0.25 & 0.46 & 0.31 & $0.04(0.07)$ \\
$20 \mathrm{~nm}$ & $120^{\circ} \mathrm{C}$ & P3HT & $60 \mathrm{~nm}$ & 0.46 & 1.88 & 0.42 & $0.40(0.45)$ \\
$20 \mathrm{~nm}$ & $150^{\circ} \mathrm{C}$ & P3HT & $60 \mathrm{~nm}$ & 0.53 & 1.73 & 0.53 & $0.52(0.56)$ \\
$20 \mathrm{~nm}$ & $180{ }^{\circ} \mathrm{C}$ & P3HT & $60 \mathrm{~nm}$ & 0.45 & 1.58 & 0.46 & $0.35(0.35)$ \\
$50 \mathrm{~nm}$ & $150^{\circ} \mathrm{C}$ & P3HT & $60 \mathrm{~nm}$ & 0.59 & 0.26 & 0.25 & $0.04(0.05)$ \\
$20 \mathrm{~nm}$ & $150^{\circ} \mathrm{C}$ & P3HT & $40 \mathrm{~nm}$ & 0.49 & 1.80 & 0.47 & $0.46(0.49)$ \\
$20 \mathrm{~nm}$ & $150^{\circ} \mathrm{C}$ & P3HT & $90 \mathrm{~nm}$ & 0.51 & 1.31 & 0.48 & $0.34(0.36)$ \\
\hline $0 \mathrm{~nm}$ & ---- & PTB7 & $45 \mathrm{~nm}$ & 0.08 & 0.74 & 0.25 & $0.013(0.025)$ \\
$20 \mathrm{~nm}$ & $120^{\circ} \mathrm{C}$ & PTB7 & $45 \mathrm{~nm}$ & 0.75 & 1.14 & 0.40 & $0.34(0.35)$ \\
$20 \mathrm{~nm}$ & $150^{\circ} \mathrm{C}$ & PTB7 & $45 \mathrm{~nm}$ & 0.73 & 1.65 & 0.45 & $0.53(0.57)$ \\
$20 \mathrm{~nm}$ & $180^{\circ} \mathrm{C}$ & PTB7 & $45 \mathrm{~nm}$ & 0.70 & 1.32 & 0.44 & $0.40(0.46)$ \\
$20 \mathrm{~nm}$ & $150^{\circ} \mathrm{C}$ & PTB7 & $60 \mathrm{~nm}$ & 0.72 & 1.45 & 0.40 & $0.41(0.43)$ \\
$20 \mathrm{~nm}$ & $150^{\circ} \mathrm{C}$ & PTB7 & $85 \mathrm{~nm}$ & 0.78 & 0.91 & 0.47 & $0.33(0.36)$ \\
\hline
\end{tabular}


Table S3. The reported photovoltaic parameters of bulk heterojunction OPV devices utilized mono PDI as acceptor and P3HT as donor. The molecular structure are displayed below.

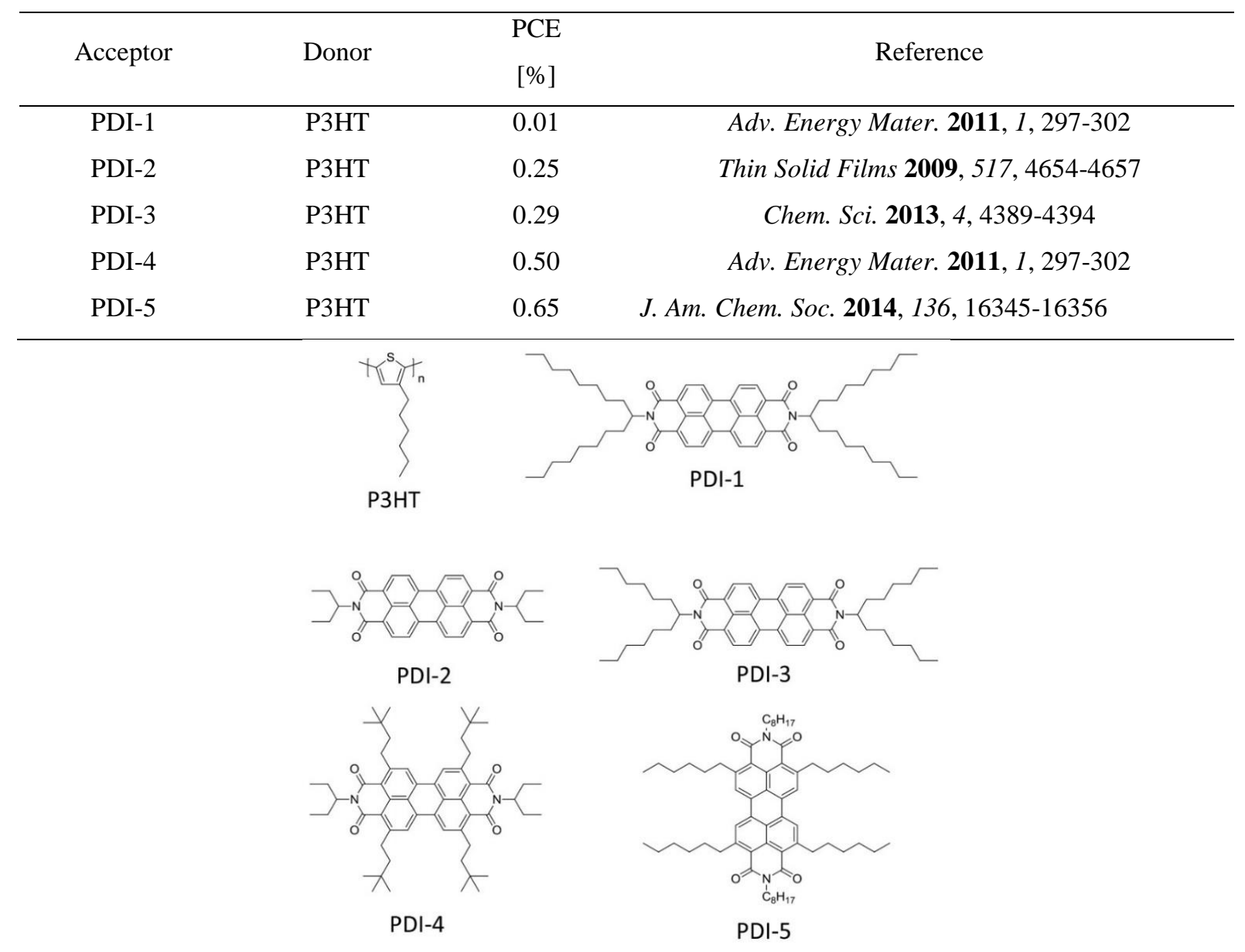

Table S4. Photovoltaic parameters of PM-HJ devices. The results are average values calculated from 6 cells.

\begin{tabular}{|c|c|c|c|c|c|c|}
\hline $\begin{array}{l}\text { CPN film } \\
\text { thickness }\end{array}$ & $\mathrm{T}_{\mathrm{rxn}}$ & BHJ & $\begin{array}{l}V_{\mathrm{oc}} \\
{[\mathrm{V}]}\end{array}$ & $\begin{array}{c}J_{\mathrm{sc}} \\
{\left[\mathrm{mA} \mathrm{cm}^{-2}\right]}\end{array}$ & FF & $\begin{array}{c}\mathrm{PCE}_{\mathrm{avg}(\max )} \\
{[\%]}\end{array}$ \\
\hline $0 \mathrm{~nm}$ & ---- & P3HT:PC ${ }_{61} \mathrm{BM}$ & 0.55 & 10.70 & 0.56 & $3.34(3.79)$ \\
\hline $10 \mathrm{~nm}$ & $120^{\circ} \mathrm{C}$ & P3HT:PC ${ }_{61} \mathrm{BM}$ & 0.55 & 13.03 & 0.57 & $4.17(4.40)$ \\
\hline $10 \mathrm{~nm}$ & $150^{\circ} \mathrm{C}$ & P3HT:PC ${ }_{61} \mathrm{BM}$ & 0.55 & 12.88 & 0.56 & $4.07(4.26)$ \\
\hline $10 \mathrm{~nm}$ & $180^{\circ} \mathrm{C}$ & P3HT:PC ${ }_{61} \mathrm{BM}$ & 0.54 & 11.34 & 0.48 & $3.33(3.55)$ \\
\hline $20 \mathrm{~nm}$ & $150^{\circ} \mathrm{C}$ & P3HT:PC ${ }_{61} \mathrm{BM}$ & 0.54 & 12.08 & 0.50 & $3.47(3.55)$ \\
\hline $0 \mathrm{~nm}$ & $\begin{array}{l}--- \\
\end{array}$ & PTB7:PC ${ }_{71} \mathrm{BM}$ & 0.73 & 14.93 & 0.67 & $6.95(7.01)$ \\
\hline $10 \mathrm{~nm}$ & $120^{\circ} \mathrm{C}$ & PTB7:PC ${ }_{71} \mathrm{BM}$ & 0.75 & 16.65 & 0.65 & $7.94(8.19)$ \\
\hline $10 \mathrm{~nm}$ & $150^{\circ} \mathrm{C}$ & PTB7:PC ${ }_{71} \mathrm{BM}$ & 0.75 & 16.12 & 0.65 & $7.58(7.79)$ \\
\hline $10 \mathrm{~nm}$ & $180^{\circ} \mathrm{C}$ & PTB7:PC ${ }_{71} \mathrm{BM}$ & 0.75 & 15.15 & 0.65 & $7.13(7.37)$ \\
\hline $20 \mathrm{~nm}$ & $150^{\circ} \mathrm{C}$ & PTB7:PC ${ }_{71} \mathrm{BM}$ & 0.75 & 17.23 & 0.60 & 7.54 (7.59) \\
\hline $35 \mathrm{~nm}$ & $150^{\circ} \mathrm{C}$ & PTB7:PC ${ }_{71}$ BM & 0.75 & 14.88 & 0.32 & $3.47(3.67)$ \\
\hline
\end{tabular}

